\title{
Interglacial variability (MIS 5 and MIS 7) and dinoflagellate cyst assemblages in the Bay of Biscay (North Atlantic)
}

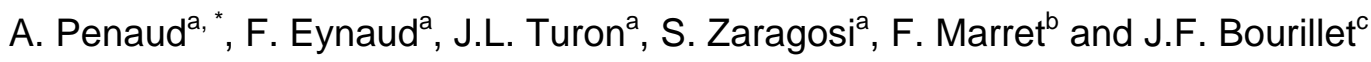 \\ ${ }^{a}$ Université Bordeaux 1, Avenue des Facultés, CNRS, UMR 5805-EPOC, Talence, F-33405, France \\ ${ }^{\mathrm{b}}$ Department of Geography, University of Liverpool, Roxby Building, Liverpool, L69 7 ZT, United Kingdom \\ c IFREMER, Département Géosciences Marines, Laboratoire Environnements Sédimentaires, BP 70-29280 \\ Plouzané, France \\ *: Corresponding author : A. Penaud, email address : a.penaud@epoc.u-bordeaux1.fr
}

\begin{abstract}
:
The interglacial periods of the late Quaternary are frequently investigated as they constitute potential analogues for our modern climate and may shed light on the key questions of natural climate variability and future developments. The aim of this work is to reconstruct the paleoenvironmental history of Marine Isotope Stages (MIS) 5 and 7 in deep-sea sediments of the northern Bay of Biscay (North East Atlantic Ocean). On the basis of a multiproxy compilation, including analysis of dinoflagellate cyst assemblages, we discuss the nature of the paleoenvironmental and paleoclimate changes that took place in this region.

Recurrent successions of species marking the beginning and the Termination of the Interglacial Complexes (MIS 5 and MIS 7) revealed a coherent scheme of water mass migration during these key transitional periods. Moreover, our data extend knowledge about the ecology of several dinoflagellate taxa. In particular, we discuss the ecology of Spiniferites septentrionalis and note that this species can be used as a biostratigraphical tracer in North Atlantic Quaternary sediments, until a major event of iceberg calving occurred during MIS 6, dated to around $150 \mathrm{ka} \mathrm{BP.}$

The dinocyst Spiniferites mirabilis appears to be an important proxy for recognizing warm intervals within Interglacial Complexes. During MIS 5e, the Last Interglacial, this species is represented by the highest percentages ever recorded in sediments from the North Atlantic region. Peak occurrence of this species during MIS 7 indicates that substage MIS 7c, the second warm interval of the Penultimate Interglacial, represents the climatic optimum during the MIS 7 Interglacial Complex.
\end{abstract}

Keywords: Dinoflagellate cysts; Foraminifera; Celtic-Armorican margin; Marine Isotope Stages (MIS) 5 and 7; Interglacial Complexes; Climatic optima 


\section{Introduction}

The interglacial periods of the Quaternary have been widely studied since they represent the most probable analogues for our modern warm climate. In order to better understand our present interglacial period, the Holocene, several paleoclimatic studies have focused on the transition between interglacial and glacial stages to estimate the length of the warm stages and to explain their duration (e. g. Kukla et al., 1997; Winograd et al., 1997; Forsström, 2001; Tzedakis et al., 2004; Kukla, 2005). Marine Isotope Stage (MIS) 5, or at least part of this Interglacial Complex (Turon, 1984b) also referred as the Eemian on the continent, or the Last Interglacial, has long been thought to represent the closest equivalent for the Holocene. However, Loutre and Berger (2003) considered MIS 11 to be a better analogue for MIS 1 and the future, judging by the good linear correlation of the insolation signal of these two periods (low amplitude variations for both MIS 11 and MIS 1). Nevertheless, looking at other Interglacial Complexes with high amplitudes of insolation changes, like MIS 7, allows a better understanding of the response of the climate system under strong orbital forcing.

In this study, we have investigated the paleoenvironmental history of MIS 5 and MIS 7 (also referred to Interglacial Complexes 5 and 7) using a giant CALYPSO core retrieved in the Bay of Biscay (core MD03-2692; temperate North Atlantic), covering the last three climatic cycles. We have carried out a detailed micropaleontological analysis based on organic walled dinoflagellate cysts (dinocysts) to infer patterns of sea-surface hydrological changes. This work represents the first documentation of the ultimate and penultimate interglacial stages based on dinocysts at this latitude of the North Atlantic. For more than two decades, dinocysts have proved to be very helpful to reconstruct Quaternary paleoenvironments (e. g. Turon, 1984a; Matthiessen, 1995; Rochon et al., 1999; Devillers, 2000; Eynaud et al., 2000; de Vernal et al., 2001; Zonneveld et al., 2001b; Mudie et al., 2002; de Vernal et al., 2005; Grøsfjeld et al., 2006). Less than 20\% of dinoflagellates produce cysts that are well preserved in sediments (Head, 1996), giving therefore a fragmentary picture of the original dinoflagellate population. The cysts are protected by an organic membrane chemically similar to that of pollen and are thus highly resistant in comparison with siliceous or calcareous microfossils which are sensitive to dissolution. The distribution and relative abundance of dinocysts are associated with the physico-chemical parameters of the overlying water masses (temperature, salinity, sea-ice cover, seasonality, availability of nutrient), allowing micropaleontologists to reconstruct paleohydrological changes throughout geological time (e.g. Harland, 1983; Turon, 1984a). In this study, dinocyst data have been compared with other proxies previously obtained from the same core (coarse - >150 $\mu \mathrm{m}$ lithic grain concentrations, abundances of the polar foraminifera Neogloboquadrina pachyderma sinistral, benthic $\delta^{13} \mathrm{C}$; Mojtahid et al., 2005). We discuss their paleoenvironmental and paleoclimatological significance within the stratigraphical framework basically provided by benthic isotopes $\left(\delta^{18} \mathrm{O}\right)$.

\section{Material and environmental setting}

The studied CALYPSO core MD03-2692 (4650' N; 9³1'W; 4064 m water depth; $39 \mathrm{~m}$ length) was recovered during the SEDICAR cruise onboard the oceanographic RV Marion Dufresne II of the Institut Polaire Paul-Emile Victor (IPEV, Bourillet and Turon, 2003). It provides a high-resolution paleoceanographic record from MIS 10 onwards, thus covering one of the longest temporal intervals documented in the area. Core MD03-2692 is located in the northern part of the Bay of Biscay along the Celtic-Armorican margin, in line with the English Channel and the Irish Sea (Fig. 1). It was retrieved from the Trevelyan Escarpment, 500 meters higher than the abyssal plain in this area; its location on a seamount explains why calm sedimentary processes prevail, and why sedimentation is not affected by turbidite currents present on the slope and the rise of the Celtic-Armorican margin around the escarpment (Zaragosi et al., 2001, 2006; Toucanne et al., in press). Indeed, this long period of time is characterized by a continuous facies of rapidly accumulating hemipelagic clays (Mojtahid et al., 2005). However, increasing concentrations of large detrital grains ( $>150 \mu \mathrm{m}$ ) observed in the core MD03-2692 (Mojtahid et al., 2005) reveal several events of iceberg calving.

Four deep water masses control the present sedimentation (Frew et al., 2000): the Lower Deep Water (LDW, abyssal water mass), overlaid by the North East Atlantic Deep Water (NEADW, $2800 \mathrm{~m}$ depth), the Labrador Sea Water (LSW, $1500 \mathrm{~m}$ depth) and the Mediterranean Outflow Water (MOW, $800 \mathrm{~m}$ depth). Surface waters derive from the North Atlantic Drift (NAD), the major surface current of the 
North Atlantic Ocean that also constitutes a key branch of the thermohaline circulation, supplying boreal basins with warm and salty waters (Broecker et al., 1990).

\section{Methods}

\subsection{Dinoflagellate cysts analysis}

Dinocysts were retrieved from the $<150 \mu \mathrm{m}$ fraction. Samples were taken every $10 \mathrm{~cm}$ in the core. 153 slides were analysed from MIS 7 to MIS 5 between 3220 and $1700 \mathrm{~cm}$. The preparation technique followed the protocol described by de Vernal et al. (1999) and Rochon et al. (1999), slightly modified at the UMR EPOC laboratory. After chemical treatments (cold $10 \%, 25 \%$ and $50 \% \mathrm{HCl}$, cold $40 \%$ and $70 \% \mathrm{HF}$ shaken during 24 hours), the samples were sieved through $10-\mu \mathrm{m}$ nylon mesh screens. Acetolysis was not employed, so as to avoid destruction of heterotrophic species such as Polykrikaceae and Brigantedinium cysts (Marret, 1993; Combourieu-Nebout et al., 1998). The final residue was mounted between slide and coverslip with glycerine jelly coloured with fuchsin. Dinoflagellate cysts were counted using a Leica DM 6000 microscope at $400 \times$ magnification. On each sample, an average of 300 specimens was identified and counted. Dinocyst concentrations were calculated using the marker grain method (de Vernal et al., 1999): aliquot volumes of Lycopodium spores were added to each sample before chemical treatment in order to estimate palynomorph concentrations. Taxonomic identification conforms to Fensome et al. (1998) and Fensome and Williams (2004), and dinocyst assemblages were described by the percentages of each species calculated on the basis of the total dinocyst sum including unidentified taxa and excluding reworked specimens (pre-Quaternary cysts). Brigantedinium spp. includes all spherical brown cysts as it is difficult to identify them at species level. Even if the cyst wall of Brigantedinium spp. is sensitive to oxidation processes (Combourieu-Nebout et al., 1998; Zonneveld et al., 2001a), this group provides very important signals of paleoproductivity as cysts are produced during the life cycle of heterotrophic dinoflagellates.

\subsection{Benthic $\delta^{18} \mathrm{O}$ records: Stratigraphy}

The stratigraphical framework of the core is based on the $\delta^{18} \mathrm{O}$ measurements obtained on three benthic foraminiferal species (Uvigerina peregrina, Pullenia bulloides and Planulina wuellerstorfi). Isotopic data were compiled and corrected according to Duplessy et al. (1984) to obtain a composite curve; the age model was constrained (see Mojtahid et al., 2005 for analytical details) by a direct comparison with the orbital time scale derived from the SPECMAP $\delta^{18} \mathrm{O}$ curve (Martinson et al., 1987). Stage boundaries were drawn by the classical method of defining the mid-point between two extremes of the $\delta^{18} \mathrm{O}$ curve spanning the limits. We located the limits of the substages (MIS 5a to MIS $5 \mathrm{e}$ and MIS $7 \mathrm{a}$ to MIS 7e) between extreme values of the $\delta^{18} \mathrm{O}$ curve.

\subsection{Benthic $\delta^{13} \mathrm{C}$ records: Deep-Water Circulation}

Since the deep circulation is considered to be the dominant factor affecting variations in the $\delta^{13} \mathrm{C}$ of the total dissolved $\mathrm{CO}_{2}$ in the world oceans (Duplessy et al., 1984), this isotopic record allowed us to reconstruct the general trends of the deep water paleocirculation (Duplessy and Shackleton, 1985; Raymo et al., 1990; Vidal et al., 1997).

The analysis made on three benthic foraminifera (Uvigerina peregrina, Pullenia bulloides and Planulina wuellerstorfi) allowed us to obtain the most complete isotopic record possible on the core (Fig. 2). The isotopic ratios of these species required correction on account of the departure from isotopic equilibrium which is species-dependent. The carbon isotopic composition of $P$. wuellerstorfi is considered very close to that of the total dissolved $\mathrm{CO}_{2}$. To obtain normalized benthic foraminifera calcite, $U$. peregrina and $P$. bulloides were adjusted to $P$. wuellerstorfi. We added +0.90 to $U$. peregrina records (Duplessy et al., 1984), and +1.756 to $P$. bulloides records (here the value was obtained by averaging the differences between the isotopic ratios of $P$. wuellerstorfi and $P$. bulloides when both data were simultaneously available at a same level of the core). 


\subsection{Biogenic characterization: foraminifera}

The relative abundance of the polar foraminifera $N$. pachyderma s. was determined within the coarse detrital fraction $(>150 \mu \mathrm{m})$ (Mojtahid et al., 2005). At the location of the studied core, this species marks phases of invasion of polar water masses (Pujol et al., 1973; Pujol, 1980; Pujol et al., 2000). It is mostly obvious during glacial stages but also during the cold events that punctuate Interglacial Complexes (e.g. Sanchez-Goni et al., 1999; Mojtahid et al., 2005).

\subsection{Terrigenous characterization: lithic grains}

The coarse sediment fraction (> $150 \mu \mathrm{m}$ ) was previously analysed by Mojtahid et al. (2005), showing that in the Bay of Biscay, this detrital material is nearly absent from Interglacial Complexes, whereas concentrations increase during glacial Marine Isotope Stages. However, the cold substages of the Interglacial Complexes are marked by minor peaks which account for iceberg discharges. These events have been previously documented in North Atlantic deep-sea cores during MIS 5, and «C » labels (cf. Fig. 9a) were used to design Cold events occurring in marine environments and recognized by intense ice-rafting episodes and/or increases of $N$. pachyderma s. percentages (McManus et al., 1994).

\section{Results}

Dinocyst analysis in the studied section (from MIS 7 to MIS 5) shows concentrations varying between 500 and $50000 \mathrm{cysts} / \mathrm{cm}^{3}$. The highest dinocyst concentrations occur during MIS 6 and they are systematically anti-correlated to $N$. pachyderma s. percentages (Fig. 2). By contrast, they show no clear correlation with the polar foraminiferal abundances during warm interglacials MIS 5 and MIS 7 and are even lower than during the warmest intervals of MIS 6 (Fig. 2; Penaud et al., in prep.).

In our record, assemblages are dominated by Operculodinium centrocarpum, Spiniferites mirabilis, Impagidinium patulum, Bitectatodinium tepikiense, cysts of Pentapharsodinium dalei, Nematosphaeropsis labyrinthus, Brigantedinium spp., and Spiniferites septentrionalis. The biogeographic and biostratigraphic interest of the latter species is documented for the first time in this study.

\subsection{Overview of the dinocyst data for the Interglacial Complexes: MIS 5 and MIS 7}

\subsubsection{Operculodinium centrocarpum and $\delta^{13} \mathrm{C}$}

A brief look at the benthic $\delta^{13} \mathrm{C}$ record (Fig. 2) shows higher values during MIS 7 and MIS 5 than during MIS 6, reflecting the greatest efficiency of the deep oceanic circulation during interglacials rather than glacials (Duplessy et al., 1984; Raymo et al., 1990; Raymo et al., 2004). However, it is important to recognize the sharp reduction in benthic $\delta^{13} \mathrm{C}$ values within MIS 5 and MIS 7 associated with the cold substages, possibly indicating drastic reductions in North Atlantic Deep Water circulation. O. centrocarpum is considered as a cosmopolitan and temperate taxon (Turon, 1984a; Rochon et al., 1999; Marret and Zonneveld, 2003). A pattern following the North Atlantic Drift routing has been identified from its present geographical distribution in North Atlantic surface sediments. In our record this species is almost absent from MIS 6, and its percentage occurrence curve in both MIS 7 and MIS 5 shows a similar trend (Fig. 2). Indeed, this species is always limited to the Interglacial Complexes with its relative abundance progressively increasing from the base to the top of each Complex. It may be thus an additional clue to the link between $O$. centrocarpum and the North Atlantic Drift since the benthic $\delta^{13} \mathrm{C}$ signal also independently provides evidence of maximum thermohaline convection at that time.

A compilation of results that document $O$. centrocarpum distribution throughout MIS 5 in several northeastern Atlantic cores is also presented (Fig. 3). It is interesting to note the good correlation of the $\mathrm{CaCO}_{3}$ curves, reflecting probably higher calcareous microfossils productivity, with $\mathrm{O}$. centrocarpum relative abundances. The total planktonic community (phyto- and zoo-plankton) seems thus to respond consistently to the "thermohaline active" stages (MIS 5 and MIS 7). However, it is worth noting that the intervals of higher productivity, evidenced by the $\mathrm{CaCO}_{3}$ curves, are not so obvious in the dinocyst concentrations (Fig. 2), which are actually lower during MIS 5 and MIS 7 than during the 
"warm" episodes of MIS 6. This may be due to higher concentrations of nutrients in the water column during glacial times as evidenced by higher concentrations of terrigenous elements and especially of the iron (Mojtahid et al., 2005; Penaud et al., in prep.). The increase in iron can be explained by intensification in the atmospheric circulation generated by higher thermal gradients during glacial times (Joussaume, 2000), leading to more significant transport of dust.

To conclude, direct correlation of the highest $O$. centrocarpum percentages with the highest benthic $\delta^{13} \mathrm{C}$ values demonstrates the potential of combining these two proxies to document variation in the intensity of the thermohaline circulation, as reflected both in surface waters and in the deep ocean during the two last Interglacial Complexes (MIS 5 and MIS 7) in the area.

\subsubsection{Heterotrophic taxa}

Heterotrophic-related taxa have been shown to be good tracers of regions influenced by seasonal upwelling (e.g. Marret, 1994; Zonneveld et al., 2001b; Radi and de Vernal, 2004). The dominance of heterotrophic taxa was also reported from high-latitude environments (Rochon et al., 1999). In all cases, these taxa are most likely the result of prey availability, notably diatoms, resulting in high primary productivity (Radi and de Vernal, 2004). Brigantedinium spp. form the most representative heterotrophic group in core MD03-2692. Fig. 2 shows that the highest percentages of Brigantedinium spp. occur during the cold Marine Isotope Stages (end of MIS 8 and MIS 6), whereas during the Interglacial Complexes, the percentage of Brigantedinium spp. is either low and intermittently high (MIS 5), or nearly absent (MIS 7). The low percentages of these spherical brown cysts during warm spells are very well illustrated in the middle part of MIS $5 e$ for instance. This may also reflect interdinoflagellate competition with autotrophic ones dominating the assemblage at that time. Heterotrophic taxa are dominant in the coastal zone while autotrophic taxa mainly occur in the offshore area (Radi and de Vernal, 2004). Indeed, the fact that lower sea-level occurred during glacial times favoured maybe also the dominance of Brigantedinium cysts under neritic conditions with shallower waters, and the primary productivity during glacials may also have been improved by the closer location of the coring site to the continent, hence to nutrient supply.

\subsection{3. "Warm species": thermophilic taxa (Fig. 2)}

Spiniferites mirabilis is characteristic of warm temperate to temperate environments and extends as far south as $10^{\circ} \mathrm{N}$. Today it is found in abundance in the Bay of Biscay and off the coast of Portugal (Fig. 4). It prefers sea-surface temperatures between 10 and $15^{\circ} \mathrm{C}$ during winter and 15 to $22^{\circ} \mathrm{C}$ during summer (Rochon et al., 1999). Such ranges are characteristic of pleni-interglacial conditions. As a consequence, in the Bay of Biscay, stratigraphic intervals with high percentages of S. mirabilis allow us to define climatic optima within Interglacial Complexes. The beginning of the Holocene has been clearly identified in the Bay of Biscay with elevated percentages of S. mirabilis (core MD95-2002, Zaragosi et al., 2001). The same observation was made during MIS 5 (Fig. 3) further North in the South Icelandic Basin (cores MD95-2014 and MD95-2015, Eynaud et al., 2004), as well as in temperate domains of the North Atlantic with cores MD95-2004 (Rockall Through, Eynaud, 1999) and MD95-2042 (Iberian Margin, Sanchez-Goni et al., 1999) (cf. Fig. 1 for core locations). In this study, we have identified two major peaks of this species in the middle of the warm substages MIS $5 \mathrm{e}$ and MIS 7c (Fig. 2). These optima are inferred from dinocyst data and are consistent with the lightest peaks of the benthic $\delta^{18} \mathrm{O}$ curve derived from these isotope stages (events 5.5 and 7.3).

Most Impagidinium species occur in maximum frequencies in tropical to warm temperate waters between 20 and $35^{\circ} \mathrm{N}$ (except $\mathrm{I}$. pallidum) (Harland, 1983). In this study they occur only in the Interglacial Complexes (Fig. 2). The two taxa I. aculeatum and I. patulum, which are typical of subtropical domains (Turon, 1984a), mark the warm episodes throughout MIS 5 and MIS 7 . The highest abundances of these species occur within MIS 7 (7a, 7c and 7e).

\subsection{4. . .Cold species" (Fig. 2)}

Cysts of Pentapharsodinium dalei are well represented in modern sediments from polar to subpolar environments that experience sea-surface summer temperatures higher than $4^{\circ} \mathrm{C}$ (Rochon et al., 1999; Matthiessen, 1995; Marret et al., 2004; de Vernal et al., 2005). They are particularly prevalent 
as part of the spring bloom within North Atlantic fjord systems (Dale, 1977; Harland et al., 2004a, b). In our record, they are absent during the Interglacial Complexes. However, they occur in weak relative abundance during major glacial inceptions, at the beginning of the glacial stages MIS 6 and MIS 4 .

Nematosphaeropsis labyrinthus is a typical oceanic species. Its main published distribution, so far, is between 45 and $65^{\circ} \mathrm{N}$ in the North Atlantic Ocean (Rochon et al., 1999; Matthiessen, 1995; Marret et al., 2004; de Vernal et al., 2005). However, it can also be associated with nutrient-rich cool waters (Turon and Londeix, 1988; Devillers and de Vernal, 2000). We noticed that Interglacial Complexes are similarly enclosed by $N$. labyrinthus. Two marked peaks of this species are found at the inception and at the Termination of MIS 5 and MIS 7 respectively. Thus this species tends to mark the transition between glacial and interglacial conditions (and vice versa). This important finding confirms the suggestion of Turon (1984a) and Eynaud et al. (2004), concerning the transitional character of $N$. labyrinthus during events of severe hydrological changes. $N$. labyrinthus similarly marks the transition between the substages MIS 7e and MIS $7 \mathrm{~d}$ by a significant occurrence.

Spiniferites elongatus is absent at present off Western Europe (Rochon et al., 1999). It occurs frequently in sediments of Baffin Bay and of the Barents Sea (with maximum percentages of $45 \%$ close to the Novaya Zemlya Islands) and occurs also in significant numbers in the central North Atlantic between 50 and $60^{\circ} \mathrm{N}$ (Rochon et al., 1999). During almost the entire MIS $7 \mathrm{~d}$, it comprises around $15 \%$ of the assemblage, dominating together with Spiniferites septentrionalis. The fact that this species occurs specifically in our record during this cold interval reflects perhaps the extremely unusual conditions prevailing at that time.

Bitectatodinium tepikiense is at present distributed between 55 and $65^{\circ} \mathrm{N}$ in North Atlantic temperate to sub-arctic environments. Its highest recorded occurrence is found south of the Gulf of St Lawrence. This species is characteristic of areas marked by strong seasonal contrasts, with freezing winter SST, and up to $16^{\circ} \mathrm{C}$ summer SST (de Vernal et al., 2005). B. tepikiense clearly marks the cold substages of MIS 5 (5b and $5 d$ ) as it was previously observed in a southern record of the subtropical northeastern Atlantic (core MD95-2042, Eynaud et al., 2000), whereas it is less common in those of MIS 7. However, we can observe an increase of this species during the cold substage MIS 7b, as well as at the beginning and end of MIS 7d. The lower percentages obtained during the major part of MIS $7 \mathrm{~d}$ are probably linked to the coeval presence of $S$. septentrionalis and S. elongatus.

\subsubsection{Defining an ecology for Spiniferites septentrionalis (Plate 1)}

Throughout the studied core, the presence of $S$. septentrionalis constitutes a significant indicator up to MIS 6 (Fig. 2). Indeed, the taxon remains present in our core until a major event of iceberg calving occurred during this glacial stage (an event with laminated deposits discussed in Mojtahid et al., 2005; Penaud et al., in prep.). During this episode, samples were nearly barren. No benthic isotopes could be obtained due to the extremely low abundance of benthic foraminifera. As for dinocysts, their concentrations are so low that we prefer to omit the results in the palynological diagram (Fig. 2). This episode, underlined with a dark grey band in Figure 2, corresponds to extremely high sedimentation rates and likely covers a short length of time (Mojtahid et al., 2005; Penaud et al., in prep.). After this distinctive event, S. septentrionalis nearly disappears. Eynaud (1999) who studied a proximal core in the Bay of Biscay (core MD95-2002, $47^{\circ} 27^{\prime} \mathrm{N}, 08^{\circ} 32 \mathrm{~W}, 2174 \mathrm{~m}$ depth; cf. Fig. 1 for the location) did not record this species between MIS 5 and MIS 1. Therefore, it appears that the stratigraphical record of this taxon came to an end at the time of the iceberg calving mentioned above and dated to around 150-140 ka BP. This observation prompts recognition of its major significance as a biostratigraphical marker in the Bay of Biscay.

Moreover, in contrast to most of the other northern Atlantic taxa where the geographical distribution and the possible ecological preferences are fairly well known, the environmental requirements of $S$. septentrionalis are largely unknown. Few papers relate to this species since its discovery by Harland (1977) in Quaternary North Sea sediments. In Turon and Londeix (1988), S. septentrionalis appeared only as a subordinate species in Western Mediterranean sediments during Termination I (transition between MIS 2 and MIS 1). In addition, Turon (unpublished data) mentioned its occurrence in sediments from the French Atlantic Coast during a temperate phase considered as the last or penultimate interglacial. To characterize the ecological preferences of $S$. septentrionalis, we have 
carried out a multivariate analysis (Multi-Dimensional Scaling 2D) using the PRIMER application program, on samples covering MIS 7 to MIS 5 (Fig. 5). This approach generates statistical associations permitting discrimination as to whether $S$. septentrionalis is closer to groups of cysts which are associated with either cold or warm surface waters. The multi-dimensional scaling 2D revealed two groups consistent with previous works (e.g. Turon, 1984a, Eynaud, 1999; Rochon et al., 1999). These are the "warm" and "cold" taxa identified by the two major ellipses in solid and dotted line respectively (Fig. 5). Among the species with warm waters affinities, it is worth noting the proximity (low statistical distance) of the temperate species S. mirabilis with the oceanic genus Impagidinium. I. aculeatum and I. patulum are two subtropical taxa which are consistently grouped (Turon, 1984a). Among the cold species, the recognition of the association $B$. tepikiense / $N$. labyrinthus is consistent with previous studies (Eynaud et al., 2000). Finally, S. septentrionalis appears close to "cold temperate" species such as $B$. tepikiense, cysts of $P$. dalei and $N$. labyrinthus.

Concerning the distribution of S. septentrionalis throughout MIS 7, we can first underline the fact that this species marks the onset of the warm substage MIS 7e, in the same way that the cold species $N$. labyrinthus signals the beginning of MIS 5 and the first part of MIS $5 \mathrm{e}$ just before the Eemian interglacial (Fig.6). S. septentrionalis is also present during MIS $7 \mathrm{~d}$, which experienced extremely cold temperatures at a global scale that are unusual within an Interglacial Complex (Petit et al., 1999; Lea et al., 2000; Pahnke et al., 2003; Tzedakis et al., 2004; Desprat et al., 2006), as well as during MIS 7b but with lower percentages (Fig. 2).

\subsubsection{Time successions of species (Fig. 2)}

We observed recurrent successions of species both at the beginning and at the Termination of the Interglacial Complexes. These correspond to the MIS 6-5 and MIS 8-7 boundaries deduced from the stable isotope analysis. It reveals a coherent scheme concerning the migration of water masses during these key transitional periods.

From an interglacial period to a glacial one (glacial inception of MIS 7 to MIS 6, and MIS 5 to MIS 4), we observe the succession of $O$. centrocarpum, $N$. labyrinthus and cysts of $P$. dalei, the latter indicating the onset of pleni-glacial conditions. Conversely, when the climate switched from glacial to interglacial conditions (Terminations of MIS 6 to MIS 5, and MIS 8 to MIS 7), the species succession consists of $N$. labyrinthus followed by $O$. centrocarpum, the latter marking the onset of the Interglacial Complexes.

\section{Discussion}

With regard to the exploration of interglacials, MIS 5 and MIS $5 \mathrm{e}$ in particular have so far been the main focus of investigations using various marine and continental proxies (e.g. Turon, 1984b; Kukla et al., 1997; Sanchez-Goni et al., 1999; Kukla, 2005). However, the results we obtained from the dinocysts give new insights into the history of this Interglacial Complex, especially with regard to marine environments at temperate latitudes.

In previous paleoceanographic studies MIS 7 has received comparatively much less attention. Few dinocyst investigations have been carried out within this time period in the North Atlantic. CombourieuNebout et al. (1999) studied dinocysts and pollen in early Pleistocene Western Mediterranean sediments (ODP, Leg 161, site 976). Nevertheless, the investigated core consisted of a long temporal sequence revealing low resolution data. However, pollen data are available from both terrestrial (Tzedakis et al., 1997; de Beaulieu et al., 2001; Tzedakis et al., 2004) and marine environments (Desprat et al., 2006). Our investigation increases the knowledge of these temporal sequences in marine environments and broadens the pool of data on MIS 7 with dinocyst analysis.

\section{The Warm Intervals of the Interglacial Complexes : MIS 5 and MIS 7}

\section{Interglacial Intervals sensu stricto and other warm substages: towards a precise definition?}

The Eemian and the Holsteinian Interglacials (respectively warmest phases of MIS 5 and MIS 11) are the only sensu stricto Quaternary Interglacial Intervals well identified on land. Today, the Last Interglacial (Eemian) is "palynologically" defined as a period of extended forest vegetation in Western Europe, which finally declined dramatically allowing a marked expansion of cold species (open vegetation) (e. g. Sanchez-Goni et al., 1999; Shackleton et al., 2002). Whereas there are many more 
data and references relating to MIS 5 and the Eemian, very little is known about the exact timing of the Penultimate Interglacial (MIS 7), and how real Interglacial interval can be distinguished from the other warm substages within MIS 7. The deciduous forest indeed appeared in each warm substage of MIS 5 and MIS 7, characterizing each Interglacial Intervals (Tzedakis et al., 1997; Desprat et al., 2006), that is to say MIS: $5 a, 5 c, 5 e, 7 a, 7 c$, and $7 \mathrm{e}$. A major problem with MIS 7 is that there is no consensus concerning its climatic optimum. On the one hand MIS $7 \mathrm{e}$ has been considered as a climatic optimum as warm as the Holocene (de Beaulieu et al., 2001), on the other hand Tzedakis et al. (2003) assigned to MIS 7c a status of Interglacial sensu stricto as well as MIS 7e, because MIS 7c represents the floristically most diverse, complete, and long-lived forest interval of MIS 7 in Southern Europe.

\section{Ecological information provided by Spiniferites mirabilis and Impagidinium patulum (Fig. 7)}

Throughout the core the relative abundance of these two species shows significant variations which are obviously unambiguously linked to the warm intervals and to July insolation maxima at $65^{\circ} \mathrm{N}$ (Fig. 7). The highest values ever obtained for S. mirabilis (around 65\%) in Quaternary records of the North Atlantic basin enable us to locate the warmest period of the MIS 5 Interglacial Complex. Previous observations from other cores reveal that the response of S. mirabilis through MIS 5 is uniform in the North Atlantic (Fig. 3). Application of basic uniformitarian principles leads us to conclude that the highest relative abundance of this species possibly represents an important climate signal, indicating SST warmer than those in the Bay of Biscay at present. Actually this area represents undoubtedly the optimal conditions for this taxon, whose distribution in the North Atlantic Ocean at present is mapped in Figure 4. However, such high percentages have never been observed in modern North Atlantic sediments where the maximum values in the modern 'Dinocyst $n=940$ ' database (de Vernal et al., 2005) are mainly between 50 and $60 \%$ along the Iberian margin. Migration of the biogeographical fronts northwards, based on the percentage occurrence of S. mirabilis by more than $35 \%$ in core MD95-2015, was already observed by Eynaud et al. (2004; Fig. 3). This core is located at $59^{\circ} \mathrm{N}$, close to the northern limit of the extension of this species at $60^{\circ} \mathrm{N}$. It is important to note that according to our age model, in core MD03-2692, the thermal optimum of MIS 5 (S. mirabilis plateau) occurs after the beginning of MIS $5 \mathrm{e}$ (the start of MIS $5 \mathrm{e}$, deduced from the isotopic curve, occurs where $N$. labyrinthus is peaking at around $125 \mathrm{ka} \mathrm{BP}$ ). This implies that the thermal optimum occurs 6000 years after the onset of Marine Isotope Stage 5 (MIS 5). This observation is consistent with the Eemian chronology (Sanchez-Goni et al., 1999; Shackleton et al., 2003). Moreover, after the climatic optimum, S. mirabilis is still represented by small percentages (around 10\%) coeval with a peak of $I$. patulum. MIS $5 e$ can be then divided into three episodes that can be used for correlation within the North Atlantic: a cool or temperate event preceding the climatic optimum followed by a temperate period that comes to an end at the onset of MIS $5 \mathrm{~d}$, around the time when the reconstruction of the polar ice caps has begun (Sanchez-Goni et al., 1999). The two other warm substages of MIS 5 (5a and 5c), which are considered from a palynological point of view (Sanchez-Goni et al., 1999) as globally extensive interglacial intervals, are characterized by the development of the tropical taxon I. patulum. We observe that each peak occurrence of $I$. patulum correlates with the lowest values of benthic oxygen isotopes (low ice volume) and the maxima of the $65^{\circ} \mathrm{N}$ July insolation curve (Fig. 7). We consider MIS $5 \mathrm{a}$ as being slightly warmer than MIS $5 \mathrm{c}$. This is due to higher values of $I$. patulum (12\%) in MIS $5 \mathrm{a}$ compared with those of MIS $5 \mathrm{c}(8 \%)$, in addition to the contemporaneous discrete development of $S$. mirabilis (10\%). The occurrence of S. mirabilis during MIS 5 a was already observed at the Iberian Margin (core MD95-2042; Eynaud et al., 2000), and at the Gardar Drift (core MD95-2015; Eynaud, 1999; Fig. 3).

This approach, using the highest percentages of S. mirabilis as a proxy for depicting climatic optima, can likely also be applied to the other Quaternary stages. For example, the $S$. mirabilis peak around $215 \mathrm{ka}$ BP (MIS 7c) can be considered as representing the climate optimum of the Penultimate Interglacial. The lower percentages of S. mirabilis during MIS 7c (around 45\%), compared to those of MIS 5e, indicate lower SST during the climate optimum of MIS 7 than during that of MIS 5. The warmest conditions during MIS 7 were then probably closer to the actual ones in the area. I. patulum is also well represented in MIS 7c, occurring with a coeval pronounced peak. During the other warm substages of MIS 7 (MIS 7b and MIS 7d), I. patulum shows a similar configuration as in MIS 5, i.e. peak occurrences of the species conform to the lowest benthic oxygen isotope values and insolation maxima (Fig. 7). 


\section{MIS 7c: the warmest interval of the penultimate Interglacial Complex?}

Records of various contemporaneous proxies suggest that the warmest phase does not necessarily take place during the first warm substage of an Interglacial Complex.

Considering the solar radiation (Berger et Loutre, 1991) and the extension of the glaciers (SPECMAP curve, Martinson et al., 1987) between MIS 12 and MIS 7, Forsström (2001) noticed that there could be a link between these two factors and the nature of the interglacials. He suggested that a warm interglacial can only succeed a period of extensive glacial melting, and that a warm stage succeeding a minor period of glaciation will remain cooler, frequently being of an interstadial nature. Indeed, as glaciers were relatively small before MIS $7 \mathrm{e}$, when warm conditions originated, the ice melting may not have been sufficient to trigger a significant isostatic rebound. Therefore, this dynamic phenomenon could not have amplified calving of glacier through feedback mechanisms. The remaining ice during MIS 7e must have induced a comparatively cooler climate. It is worth noting that the $\delta^{18} \mathrm{O}$ benthicstack described by Martinson et al. (1987) and our $\delta^{18} \mathrm{O}$ curve also suggest that there was more ice during MIS 7e than during MIS 7c. The following episode, MIS 7d, represents an interval of severe climate conditions as indicated by the major peak of $N$. pachyderma s. and the extremely light benthic carbon isotopes (Fig. 2). During this episode, large glaciers and conditions equivalent to pleni-glacial ones developed. The glaciers melted rapidly due to the considerable solar radiation maximum leading to MIS 7c (Fig. 7). MIS 7c thus seems to meet the conditions which are critical for the development of a warm Interglacial according to Forsström (2001).

Moreover, the sea-level curve of Waelbroeck et al. (2002), which covers the last four climatic cycles, shows three warm intervals during MIS 7 of roughly similar magnitude. Estimates during MIS 7c indicate that this substage is characterized by slightly higher sea-level than the other warm spells. However, other published data disagree about the sea-level during MIS 7a and MIS 7c. According to Bard et al. (2002), the sea-level was periodically higher during MIS 7c than during MIS 7a. However, Shackleton (2000), and Thompson and Goldstein (2005), the latest ones studying Barbados corals, came to the opposite conclusion.

Finally, Tzedakis et al. (2004) showed extensive forest development during the warm substages of MIS 7 in all the studied sequences on land. However, it was difficult to assess which of the two phases, the oldest (MIS 7e), or the youngest (MIS 7c), was the warmer. Desprat et al. (2006), investigating a north-western Iberian margin core (MD01-2447), associated three major humid temperate forested phases with the lightest isotopic substages of MIS 7 (Fig. 8b). A premature ending of the first forest episode (Arousa episode) during MIS 7e was observed on account of the extremely cold following substage MIS 7d. Based on the recognition of the weak development of Mediterranean plants, Desprat et al. (2006) did not consider the climatic optimum of MIS 7e to be particularly warm. The two succeeding forested periods, Ribeira and Rianxo, correspond to MIS 7c and MIS 7a respectively. Transfer functions applied on planktonic foraminiferal assemblages on the same Iberian margin core led to the conclusion that the three long lasting forested intervals were associated with contemporaneous warming of the ocean surface waters in summer at a similar magnitude, and to slightly higher temperatures in winter during MIS $7 \mathrm{a}\left(+1.5^{\circ} \mathrm{C}\right)$. However, qualitative consideration of the assemblage indicates that the warmest planktonic foraminiferal species are more abundant during the beginning of the second warm episode of MIS 7, which represents the first part of the Ribeira interval (Fig. 8b). If we considerer now the non-thermophilous plant taxa in the same interval, the lowest Poaceae abundances of MIS 7 were also recorded during the first part of the Ribeira forest between 210 and $221 \mathrm{ka}$ BP (Fig. 8b). In our core, maximum percentages of S. mirabilis and $I$. patulum, occurring according to our age model between 207 and 218 ka BP, clearly identify the climatic optimum (Fig. 8a). Different control points have been chosen to tune the benthic records of cores MD03-2692 (Celtic-Armorican margin) and MD01-2447 (north-western lberian margin) and differences in the ages of the isotopic events in the two cores vary by between 1 and 3 ka (Table 1). However, a similar duration of $11 \mathrm{ka}$ is obtained for the climatic optimum in the two cores.

Conflicting conclusions concerning sea-level and climatic optimum during MIS 7 exist. Nevertheless, the three warm substages often showed equivalent warming conditions in previous studies. It became apparent during our work that the distribution of S. mirabilis throughout MIS 7 in the Bay of Biscay enables the identification of a climatic optimum during substage MIS 7c. We have to keep in mind that the first warm substages of Interglacial Complexes are not systematically associated with climatic optima as de Beaulieu et al. (2001) suggested on the basis of pollen data from the Velay sequence (Massif Central, France). They concluded that "each of the great temperate "complexes" corresponding to MIS 11, 9, 7 and 5 presents a similar climatic structure marked by a succession of at least three temperate episodes, the first being the warmest". Obviously, this is not the case for MIS 7 . 
The recognition of the Penultimate Interglacial is essential as it extends the list of potential analogous situations to the present Interglacial, the Holocene.

\section{The Cold Intervals of the Interglacial Complexes : MIS 5 and MIS 7}

Based on the increase in IRD and/or the occurrence of $N$. pachyderma s. in two cores from the northeastern Atlantic, McManus et al. (1994) documented a succession of marine cold water events during MIS 5, labelled C19 to C25. These tracers indicate migration of polar iceberg-laden water mass into the temperate Atlantic belt during the last Interglacial Complex. All these cold events, except C23, were identified in our core (Fig. 9a). C21 and C24 correspond to the heaviest benthic isotope values in MIS 5b and MIS 5d (McManus et al., 1994; Chapman and Shackleton, 1999). Bitectatodinium tepikiense clearly increases during the cold substages of MIS 5 accompanied by low percentages of Nematosphaeropsis labyrinthus (Fig. 9a). These two species were also observed in Atlantic cores from the Iberian margin (MD95-2042, Fig. 9c, Eynaud et al., 2000) and the Rockall Through (MD952004, Fig. 9b, Eynaud, 1999). However, this association doesn't appear synchronously at the onset of MIS 5, in core MD03-2692 (Fig. 9a) nor in core MD95-2004 (Fig. 9b), where a lag is observed between Bitectatodinium tepikiense marking the end of the glacial stage (MIS 6) with extremely high relative abundances, and Nematosphaeropsis labyrinthus appearing at a transitional step between MIS 6 and MIS 5. The records are strikingly similar for these two sequences. It reveals that cold periods are displayed in the same way in the north-eastern Atlantic, at least between 45 and $55^{\circ} \mathrm{N}$.

These two latter species are thus important recurrent species characteristic of the severe climatic conditions characterizing sea-surface waters of the temperate north-eastern Atlantic throughout MIS 5 , at least between 37 and $55^{\circ} \mathrm{N}$. This is particularly true for $B$. tepikiense whose high percentages correlate very well with the heavy values of the $\delta^{18} \mathrm{O}$ curve (Fig. 9a and 9c) and with the low values of the $\mathrm{CaCO}_{3}$ curve (Fig. 9b). However, the association Bitectatodinium tepikiense / Nematosphaeropsis labyrinthus cannot be applied as indicators of the cold substages of MIS 7, which show a very different pattern. MIS 7 indeed experienced insolation of very high amplitudes leading to anomalous climatic conditions inside the Interglacial Complex. In this complex Spiniferites septentrionalis characterizes the coldest episodes (Fig. 8a). During the extremely cold interval of MIS $7 \mathrm{~d}$ which correlates with very low insolation values $\left(65^{\circ} \mathrm{N}\right)$, we observe a strong development of $N$. pachyderma s. and benthic oxygen isotope values close to those characteristic of glacial conditions (Fig. 8a). Spiniferites septentrionalis and Spiniferites elongatus co-exist during this unusual interval. They occur with possible iceberg discharges revealed by the relatively high concentrations of coarse $(>150 \mu \mathrm{m})$ detrital grains that probably represent IRD (Motjahid et al., 2005, Zaragosi et al., 2006; Toucanne et al., in press). As for MIS $7 \mathrm{~b}$, it seems to be a period of very weak ice accumulation judging by the light benthic oxygen isotope values. Moreover, marine environments do not seem to have been affected by iceberg discharges at our latitude judging by the absence of coarse detrital material at that time; also S. septentrionalis is represented by lower percentages than during MIS 7d (Fig. 8a).

\section{Conclusion}

The dinocyst records of core MD03-2692 (Celtic-Armorican margin) from the temperate latitudes of the North Atlantic have brought to light significant paleoenvironmental changes from the beginning of MIS 7 to the end of MIS 5. The total dinocyst concentrations agree with those of most other studies indicating higher biological productivity during the warm intervals of glacial stages compared to those of interglacial ones. Similar time successions of species during the onset and Termination of Interglacial Complexes reveal the shift of sea-surface bioclimatic belts during these key transitional periods. Moreover, we have established more securely the environmental requirements of several dinocyst species, particularly S. septentrionalis. The distribution of this species has been poorly documented since it was described for the first time. This species is abundant during MIS $7 \mathrm{~d}$, which is a marked substage of MIS 7 where cold climate conditions close to glacial ones seem to have occurred. We demonstrate that in northern Atlantic sediments, this species could be considered as a biostratigraphical tracer since it disappears after $140 \mathrm{ka} \mathrm{BP}$, an event corresponding to a major event of iceberg calving during MIS 6.

The investigation of the warm intervals of MIS 7 and MIS 5 contributes significantly to defining the climatic optima of the Interglacial Complexes. It confirms the warmer character of the MIS $5 \mathrm{e}$ compared with both the other interglacial substages of MIS 5 as well as present day conditions. By 
analogy we deduced from the largest S. mirabilis peak during MIS 7, occurring in the middle of MIS 7c, that this period corresponds to the "true" Penultimate Interglacial. It implies that the structure of MIS 7 differs significantly from that of MIS 5 , having a climatic optimum localised during the second step of warming within MIS 7 and not during the first one. Indeed, it reveals that different Interglacial Complexes can evolve variously and have different climatic structure.

\section{Acknowledgements}

Thanks to IPEV, the captain and the crew of the Marion Dufresne, and the scientific team of the SEDICAR cruise. We wish to thank Mr. Y. Balut for his assistance at sea and M. Castera, M. Georget and $\mathrm{O}$. Ther for invaluable technical assistance at the laboratory. We gratefully acknowledge the reviewers, in particular Kari Grøsfjeld whose comments permit to greatly improve this manuscript. Finally, we gratefully acknowledge Frank Oldfield for the English revision. Part of this study was supported by the French CNRS and the French contract of the ANR PICC. This is an U.M.R. / EPOC C.N.R.S. 5805 contribution No 1675.

\section{References}

Bard, E., Antonioli, F., Silenzi, S., 2002. Sea-level during the penultimate interglacial period based on submerged stalagmite from Argentarola Cave (Italy). Earth and Planetary Science Letters 196, 135146.

Berger, A., Loutre, M.F., 1991. Insolation values for the climate of the last 10 million years. Quat. Sci. Rev. 10, 297-317.

Bond, G., Heinrich, H., Broecker, W., Labeyrie, L., McManus, J., Andrews, J., Huon, S., Jantschik, R., Clasen, S., Simet, C., Tedesco, C., Klas, M., Bonani, G., Ivy, S., 1992. Evidence for massive discharges of icebergs into the North Atlantic Ocean during the last glacial period. Nature 360, 246249.

Bourillet, J.-F., Turon, J.-L., 2003. Rapport scientifique de la mission MD133/SEDICAR. OCE/2003/04. Les Rapports de Campagne à la Mer IPEV, Brest, 150 pp.

Broecker, W.S., Bond, G., Klas, M., 1990. A salt oscillator in the glacial Atlantic? 1. The concept. Paleoceanography 5(4), 469-477.

Chapman, M.R., Shackleton, N.J., 1999. Global ice-volume fluctuations, North Atlantic ice-rafting events, and deep-ocean circulation changes between 130 and 70 ka. Geology 27, 795-798.

Combourieu-Nebout, N., Paterne, M., Turon, J.L., Siani, G., 1998. A high resolution record of the last deglaciation in the central Mediterranean Sea: palaeovegetation and palaeohydrological evolution. Quat. Sci. Rev. 17, 303-317.

Combourieu-Nebout, N., Londeix, L., Baudin, F., Turon J-L., von Grafenstein, R., Zahn, R., 1999. 36. Quaternary marine and continental paleoenvironments in the Western Mediterranean (Site 976, Alboran Sea): Palynological evidence. Proceedings of the Ocean Drilling Program, Scientific Results, Vol. 161.

Dale, B., 1977. New observations on Peridinium faeroense Paulsen (1905), and classification of small orthoperidinoid dinoflagellates. British Phycological Journal 12, 241-253.

de Beaulieu, J.L., Andrieu-Ponel, V., Reille, M., Grüger, E., Tzedakis, P.C., Svobodova, H., 2001. An attempt at correlation between the Velay pollen sequence and the Middle Pleistocene stratigraphy from central Europe. Quat. Sci. Rev. 20, 1593-1602. 
Desprat, S., Sanchez-Goni, M.F., Turon, J.L., Duprat, J., Malaizé, B., Peypouquet, J.P., 2006. Climatic variability of Marine Isotope Stage 7: direct land-sea-ice correlation from a multiproxy analysis of a north-western Iberian margin deep-sea core. Quat. Sci. Rev. 25, 1010-1026.

de Vernal, A., Henry, M., Bilodeau, G., 1999. Technique de préparation et d'analyse en micropaléontologie. Les Cahiers du GEOTOP vol. 3, Université du Québec à Montréal, Montréal, Canada.

de Vernal, A., Henry, M., Matthiessen, J., Mudie, P.J., Rochon, A., Boessenkool, K.P., Eynaud, F., Grøsfjeld, K., Guiot, J., Hamel, D., Harland, R., Head, M.J., Kunz-Pirrung, M., Levac, E., Loucheur, V., Peyron, O., Pospelova, V., Radi, T., Turon, J.-L., Voronina, E., 2001. Dinoflagellate cyst assemblages as tracers of sea-surface conditions in the Northern North Atlantic, Arctic and sub-Arctic seas: The new ' $n=677$ ' data base and its application for quantitative palaeoceanographic reconstruction. Journal of Quaternary Sciences 16, 681-698.

de Vernal, A., Eynaud, F., Henry, M., Hillaire-Marcel, C., Londeix, L., Mangin, S., Matthiessen, J., Marret, F., Radi, T., Rochon, A., Solignac, S., Turon, J.L., 2005. Reconstruction of sea-surface conditions at middle to high latitudes of the Northern Hemisphere during the last glacial maximum (LGM) based on dinoflagellate cyst assemblages. Quat. Sci. Rev. 24, 897-924.

Devillers, R., de Vernal, A., 2000. Distribution of dinoflagellate cysts in surface sediments of the northern North Atlantic in relation to nutrient content and productivity in surface waters. Marine Geology 166, 103-124.

Duplessy, J.C., Shackleton, N.J., Matthews, R.K., Prell, W., Ruddiman, W.F., Caralp, M., Hendy, C.H., 1984. 13C Record of Benthic foraminifera in the last interglacial Ocean: Implications for the Carbon Cycle and the global deep Water circulation. Quat. Res. 21, 225-243.

Duplessy, J.C., Shackleton, N.J., 1985. Response of global deep-water circulation to Earth's climate change $135,000-107,000$ years ago. Nature $316,500-506$.

Eynaud F., 1999. Kystes de Dinoflagellés et Evolution paléoclimatique et paléohydrologique de I'Atlantique Nord au cours du Dernier Cycle Climatique du Quaternaire. PhD, Bordeaux 1 Univ., 291 pp.

Eynaud, F., Turon, J.L., Sanchez-Goni, M.F., Gendreau, S., 2000. Dinoflagellate cyst evidence of "Heinrich-like events" off Portugal during the marine isotopic stage 5. Mar. Micropal. 40, 9-21.

Eynaud F., Turon J.L., Duprat J., 2004. Comparison of the Holocene and Eemian palaeoenvironments in the South-Icelandic basin: dinoflagellate cysts as proxies for the North Atlantic surface circulation. Review of Paleobotany and Palynology 128, 55-79.

Fensome, R.A., MacRae, R.A., Williams, G.L., 1998. DINOFLAJ. Geological Survey of Canada Open File, 3653.

Fensome, R.A., Williams, G.L., 2004. The Lentin and Williams index of fossil dinoflagellates, 2004 edition. AASP Foundation Contributions Series, vol. 42. 909 pp.

Forsström, L., 2001. Duration of interglacials: a controversial question. Quat. Sci. Rev. 20, 1577-1586.

Frew, R.D., Dennis, P.F., Karen, J.H., Michael, P.M., Steven, M.B., 2000. The oxygen isotope composition of water masses in the northern North Atlantic. Deep-Sea Res. Part 1, Oceanogr. Res. Pap. 47, 2265-2286.

Grøsfjeld, K., Funder, S., Seidenkrantz, M.S., Glaister, C., 2006. Last Interglacial marine environments in the White Sea region, northwestern Russia. Boreas 35 (3), 493-520.

Harland R., 1977. Recent and late Quaternary (Flandrian and Devensian) dinoflagellate cysts from marine continental shelf sediments around the British Isles. Paleontographica 164, 87-126. 
Harland, R., 1983. Distribution maps of Recent dinoflagellate cysts in bottom sediments from the North Atlantic Ocean and adjacent seas. Paleontology 26 (2), 321-387.

Harland, R., Nordberg, K., Filipsson, H.L., 2004a. A high-resolution dinoflagellate cyst record from latest Holocene sediments in Koljö Fjord, Sweden. Review of Palaeobotany and Palynology 128, 119141.

Harland, R., Nordberg, K., Filipsson, H.L., 2004b. The seasonal occurrence of dinoflagellate cysts in surface sediments from Koljö Fjord, west coast of Sweden - a note. Review of Palaeobotany and Palynology 128, 107-117.

Head, M.J., 1996. Modern dinoflagellate cysts and their biological affinities. In "Palynology: principles and Applications. Chapter 30." (Jansonius, J., and McGregor, D.C., editors), AASP Foundation, 11971248.

Joussaume, S., 2000. Climat d'hier à demain. CEA/CNRS Editions, Paris.

Kukla, G., McManus J.F., Rousseau, D.D., Chuine, I., 1997. How long and how stable was the last interglacial? Quat. Sci. Rev. 16, 605-612.

Kukla, G., 2005. Saalian supercycle, Mindel/Riss interglacial and Milankovitch's dating. Quat. Sci. Rev. 24, 1573-1583.

Lea, D.W., Pak, D.K., Spero, H.J., 2000. Climate impact of the Late Quaternary Equatorial Pacific sea surface temperature variations. Science $289,1719-1724$.

Loutre, M.F., Berger, A., 2003. Marine Isotope Stage 11 as an analogue for the present interglacial. Global and Planetary Change 36, 209-217.

Marret, F., 1993. Les effets de l'acétolyse sur les assemblages de kystes de dinoflagellés. Palynosciences 2, 267-272.

Marret, F., 1994. Distribution of dinoflagellate cysts in recent marine sediments from the east Equatorial Atlantic (Gulf of Guinea). Review of Palaeobotany and Palynology 84, 1-22.

Marret, F., Zonneveld, K.A.F, 2003. Atlas of modern organic-walled dinoflagellate cyst distribution. Review of Palaeobotany and Palynology 125, 1-200.

Marret, F, Eiríksson, J., Knudsen, K.L., Turon, J.-L., Scourse, J.D., 2004. Distribution of dinoflagellate cyst assemblages in surface sediments from the northern and western shelf of Iceland. Review of Palaeobotany and Palynology 128, 35-53.

Martinson, D.G., Pisias, N.G., Hays, J.D., Imbrie, J., Moore, T.C., Shackleton, N.J., 1987. Age dating and the orbital theory of the ICE Ages: development of a high resolution 0 to 300,000 year chronostratigraphy. Quat. Res. 27, 1-29.

Matthiessen, J., 1995. Distribution patterns of dinoflagellate cysts and other organic-walled microfossils in recent Norwegian-Greenland Sea sediments. Mar. Micropal. 24, 307-334.

McManus, J.F., Bond, G.C., Broecker, W.S., Johnsen, S., Labeyrie, L., Higgins, S., 1994. Highresolution climate records from the North Atlantic during the last interglacial. Nature 371, 326-329.

Mojtahid, M., Eynaud, F., Zaragosi, S., Scourse, J., Bourillet, J.F., Garlan, T., 2005. Palaeoclimatology and palaeohydrography of the glacial stages on Celtic and Armorican margins over the last 360000 yrs. Marine Geology 224, 57-82.

Mudie, P.J., Rochon, A., Aksu, A.E., 2002. Pollen stratigraphy of Late Quaternary cores from Marmara Sea: Land-sea correlation and paleoclimatic history. Marine Geology 190, 233-260. 
Pahnke, K., Zahn, R., Elderfield, H., Schulz, M., 2003. 340 000-year centennial-scale marine record of Southern Hemisphere climatic oscillation. Science 301, 948-952.

Penaud, A., Eynaud, F., Turon, J.L., Zaragosi, S., Malaize, B., Toucanne, S., Bourillet, J.F., in preparation. What forced the European ice sheets history during the last two glacial stages (MIS 6 and MIS 2)? Palynological evidences.

Petit, J.R., Jouzel, J., Raynaud, D., Barkov, N.I., Barnola, J.-M., Basile, I., Bender, M., Chappellaz, J., Davis, M., Delaygue, G., Delmotte, M., Kotyakov, V.M., Legrand, M., Lipenkov, V.Y., Lorius, C., Pépin, L., Ritz, C., Saltzman, E., Stievenard, M., 1999. Climate and atmospheric history of the past 420000 years from the Vostok ice core, Antarctica. Nature 399, 429-436.

Pujol, C., Duprat, J., Gonthier, E., Moyes, J., Pujos-Lamy, A., 1973. Résultats préliminaires de l'étude effectuée par l'Institut de Géologie du Bassin d'Aquitaine sur les carottes prélevées dans le Golfe de Gascogne lors de la mission GESTLANTE IV (1ère partie 6 - 14 mars 1972). Bull. Inst. Geol. Bassin d'Aquitaine 13, 147-162.

Pujol, C., 1980. Les foraminifères planctoniques de l'Atlantique Nord au Quaternaire. EcologieStratigraphie-Environnement. Mem. Inst. Geol. Bassin d'Aquitaine 10, 254.

Pujol, C., Zaragosi, S., Grousset, F., Paterne, M., Cortijo, E., Labeyrie, L., Manthé, S., Dennielou, B., Auffret, G.A., 2000. Age dating. In "ENAM II (1996-1999) European North Atlantic Margin".

Radi, T., de Vernal, A., 2004. Dinocyst distribution in surface sediments from the northeastern Pacific margin $\left(40-60^{\circ} \mathrm{N}\right)$ in relation to hydrographic conditions, productivity and upwelling. Review of Paleobotany and Palynology 128, 169-193.

Rasmussen, T.L., Thomsen, E., Troelstra, S.R., Kuijpers, A., Prins, M.A., 2002. Millenial-scale glacial variability versus Holocene stability: changes in planktic and benthic foraminifera faunas and ocean circulation in the North Atlantic during the last 60000 years. Marine Micropal. 47, 143-176.

Raymo, M.E., Ruddiman, W.F., Shackleton, N.J., Oppo, D.W., 1990. Evolution of Atlantic-Pacific $\delta 13 C$ gradients over the last 2,5 m.y.. Earth Planet. Sci. Lett. 97, 353-368.

Raymo, M.E., Oppo, D.W., Flower, B.P., Hodell, D.A., McManus, J.F., Venz, K.A., Kleiven, K.F., Mclntyre, K., 2004. Stability of North Atlantic water masses in face of pronounced climate variability during the Pleistocene. Paleoceanography 19, PA2008 1-13.

Rochon, A., de Vernal, A., Turon, J.L., Matthiessen, J., Head, M.J., 1999. Distribution of Recent Dinoflagellate cysts in surface sediments from the North Atlantic Ocean and adjacent seas in relation to sea-surface parameters. Am. Assoc. of Stratigr. Palynol., AASP Contr. Ser. 35, 1-152.

Sanchez-Goni, M.F., Eynaud, F., Turon, J.L., Shackleton, N.J., 1999. High resolution palynological record off the Iberian margin: direct land-sea correlation for the Last Interglacial complex. Earth and Planetary Science Letters 171, 123-137.

Schmittner, A., 2005. Decline of the marine ecosystem caused by a reduction in the Atlantic overturning circulation. Nature 434, 628-633.

Shackleton, N.J., 2000. The 100,000-Year Ice-Age Cycle Identified and Found to Lag Temperature, Carbon Dioxide, and Orbital Eccentricity. Science 289, 1897-1902.

Shackleton, N.J., Chapman, M., Sanchez-Goni, M.F., Pailler, D., Lancelot, Y., 2002. The Classic Marine Isotope Substage 5e. Quat. Res. 58, 14-16.

Shackleton, N.J., Sanchez-Goni, M.F., Pailler, D., Lancelot, Y., 2003. Marine isotope substage 5e and the Eemian interglacial. Global and Planetary Change 36 (3), 151-155.

Thompson, W.G., Goldstein, S.L., 2005. Open-System Coral Ages Reveal Persistent Suborbital SeaLevel Cycles. Science 308, 401-404. 
Toucanne, S., Zaragosi, S., Bourillet, J.F., Naughton, F., Cremer, M., Eynaud, F., Dennielou, B., 2008. Activity of the turbidite levees of the Celtic-Armorican margin (Bay of Biscay) during the last 30,000 years: Imprints of the last European Deglaciation and Heinrich events. Marine Geology 247 (1-2), 84103.

Turon, J.-L., 1984a. Le palynoplancton dans l'environnement actuel de l'Atlantique Nord-oriental. Evolution climatique et hydrologique depuis le dernier maximum glaciaire. Mémoires de l'Institut de Géologie du Bassin d'Aquitaine 17, 313 pp.

Turon, J.L., 1984b. Direct land/sea correlations in the last interglacial complex. Nature 309, 673-676.

Turon, J.L., Londeix, L., 1988. Les asssemblages de kystes de dinoflagellés en Méditerranée occidentale (Mer d'Alboran): mise en evidence de l'évolution des paléoenvironnement depuis le dernier maximum glaciaire. Bull. Centres Rech. Explor.-prod. Elf-Aquitaine 12, 313-344.

Tzedakis, P.C., Andrieu, V., de Beaulieu, J.L., Crowhurst, S., Follieri, M., Hooghiemstra, H., Magri, D., Reille, M., Sadori, L., Shackleton, N.J., Wijmstra, T.A., 1997. Comparison of terrestrial and marine records of changing climate of the last 500000 years. Earth Planet. Sci. Lett. 150, 171-176.

Tzedakis, P.C., McManus, J.F., Hooghiemstra, H., Oppo, D.W., Wijmstra, T.A., 2003. Comparison of changes in vegetation in northeast Greece with records of climate variability on orbital and suborbital frequencies over the last 450000 years. Earth and Planetary Science Letters 212, 197-212.

Tzedakis, P.C., Roucoux, K.H., de Abreu, L., Shackleton, N.J., 2004. The Duration of Forest Stages in Southern Europe and Interglacial Climate Variability. Science 306, 2231-2235.

Vidal, L., Labeyrie, L., Cortijo, E., Arnold, M., Duplessy, J.C., Michel, E., Becqué, S., van Weering, T.C.E., 1997. Evidence for changes in the North Atlantic Deep Water linked to meltwater surges during the Heinrich events. Earth Planet. Sci. Lett. 146, 13-27.

Waelbroeck, C., Labeyrie, L., Michel, E., Duplessy, J.C., McManus, J.F., Lambeck, K., Balbon, E., Labracherie, M., 2002. Sea-level and deep water temperature changes derived from benthic foraminifera isotopic records. Quat. Sci. Rev. 21, 295-305.

Winograd, I.J., Landwehr, J.M., Ludwig, K.R., Coplen, T.B., Riggs, A.C., 1997. Duration and structure of past four interglaciations. Quat. Res. 48, 141-154.

Zaragosi, S., Eynaud, F., Pujol, C., Auffret, G.A., Turon, J.L., Garlan, T., 2001. Initiation of European deglaciation as recorded in the northwestern Bay of Biscay slope environments (Meriadzek Terrace and Trevelyan Escarpment): a multi-proxy approach. Earth Planet. Sci. Lett. 188, 493-507.

Zaragosi, S., Bourillet, JF., Eynaud, F., Toucanne, S., Denhard, B., Van Toer A., Lanfumey, V., 2006. The impact of the last European deglaciation on the deep-sea turbidite systems of the CelticArmorican margin (Bay of Biscay). Geomarine Letters 26 (6), 317-329.

Zonneveld, K.A.F., Versteegh, G.J.M., de Lange, G.J., 2001a. Palaeoproductivity and postdepositional aerobic organic matter decay reflected by dinoflagellate cyst assemblages of the Eastern Mediterranean S1 sapropel. Marine Geology 172, 181-195.

Zonneveld, K.A.F., Hoek R.P., Brinkhuis, H., Willems, H., 2001b. Geographical distributions of organic-walled dinoflagellate cysts in surficial sediments of the Benguela upwelling region and their relationship to upper ocean conditions. Progress in Oceanography 48, 25-72. 
Tables

\begin{tabular}{|c|c|c|}
\hline Isotopic events & MD03-2692 (Mojtahid et al., 2005) & MD01-2447 (Desprat et al., 2006) \\
\hline 7.1 & $195 \mathrm{ka}$ & $193.07 \mathrm{ka}$ \\
\hline 7.2 & $199 \mathrm{ka}$ & $200.57 \mathrm{ka}$ \\
\hline 7.3 & $216 \mathrm{ka}$ & $219 \mathrm{ka}$ \\
\hline 7.3/7.4 mid-point & & $221.36 \mathrm{ka}$ \\
\hline 7.4 & $228 \mathrm{ka}$ & $225 \mathrm{ka}$ \\
\hline 7.5 & $238 \mathrm{ka}$ & $240 \mathrm{ka}$ \\
\hline 8.0 & $242 \mathrm{ka}$ & $244.18 \mathrm{ka}$ \\
\hline
\end{tabular}

Table 1: Ages of isotopic events in cores MD03-2692 (Mojtahid et al., 2005) and MD01-2447 (Desprat et al., 2006). Control points used to tune the two benthic records to the benthic stack of Martinson et al. (1987) are indicated with bold characters. Other isotopic events that were not used for the age model are deduced from the benthic-stack curve. These are traced for each core in order to compare the differences between the independently obtained ages.

\section{Plate}
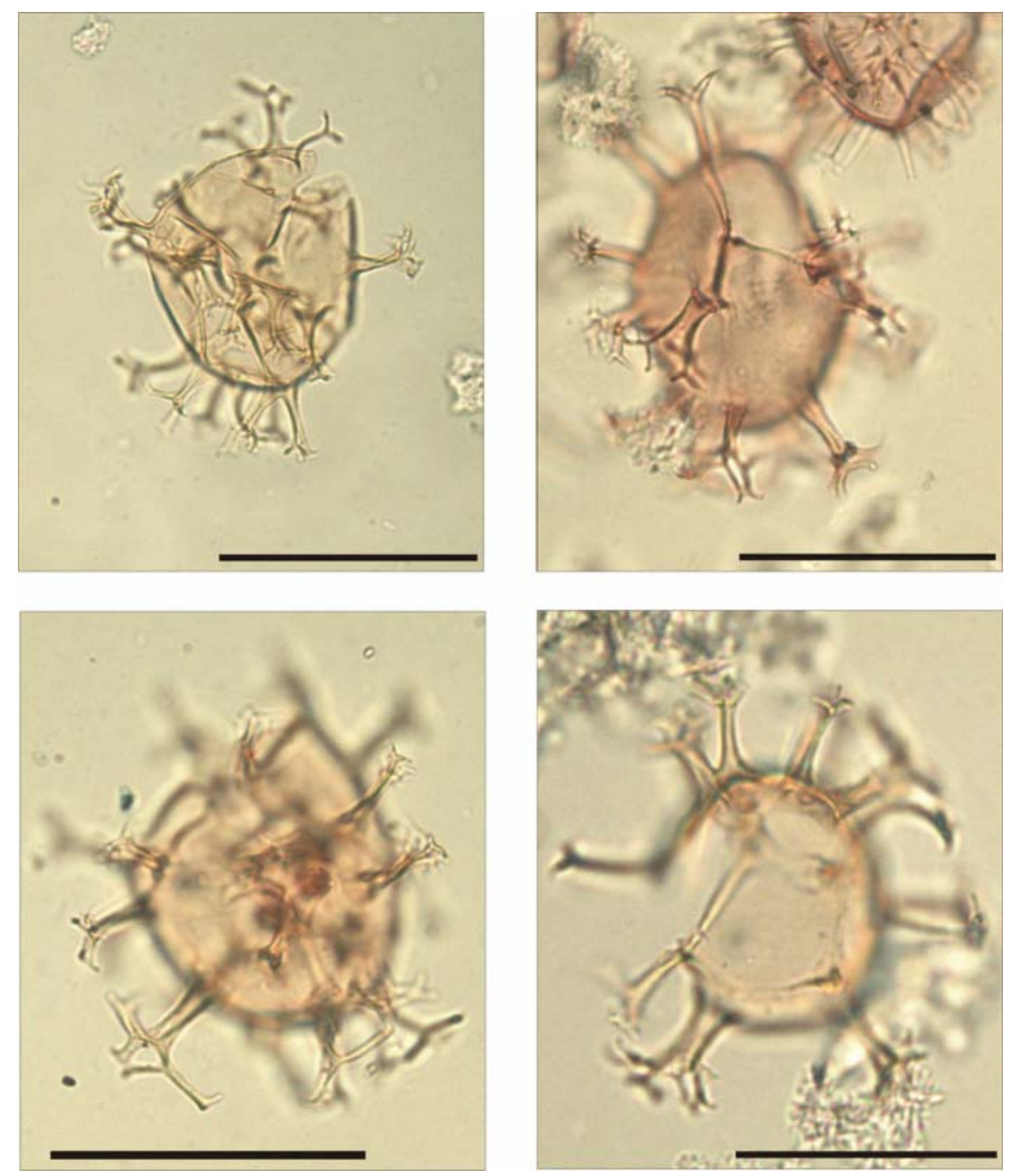

Plate 1: Different views of the species Spiniferites septentrionalis. Core MD03-2692, $2880 \mathrm{~cm}$. All photomicrographs are bright field images. Scale bar $=50 \mu \mathrm{m}$. 


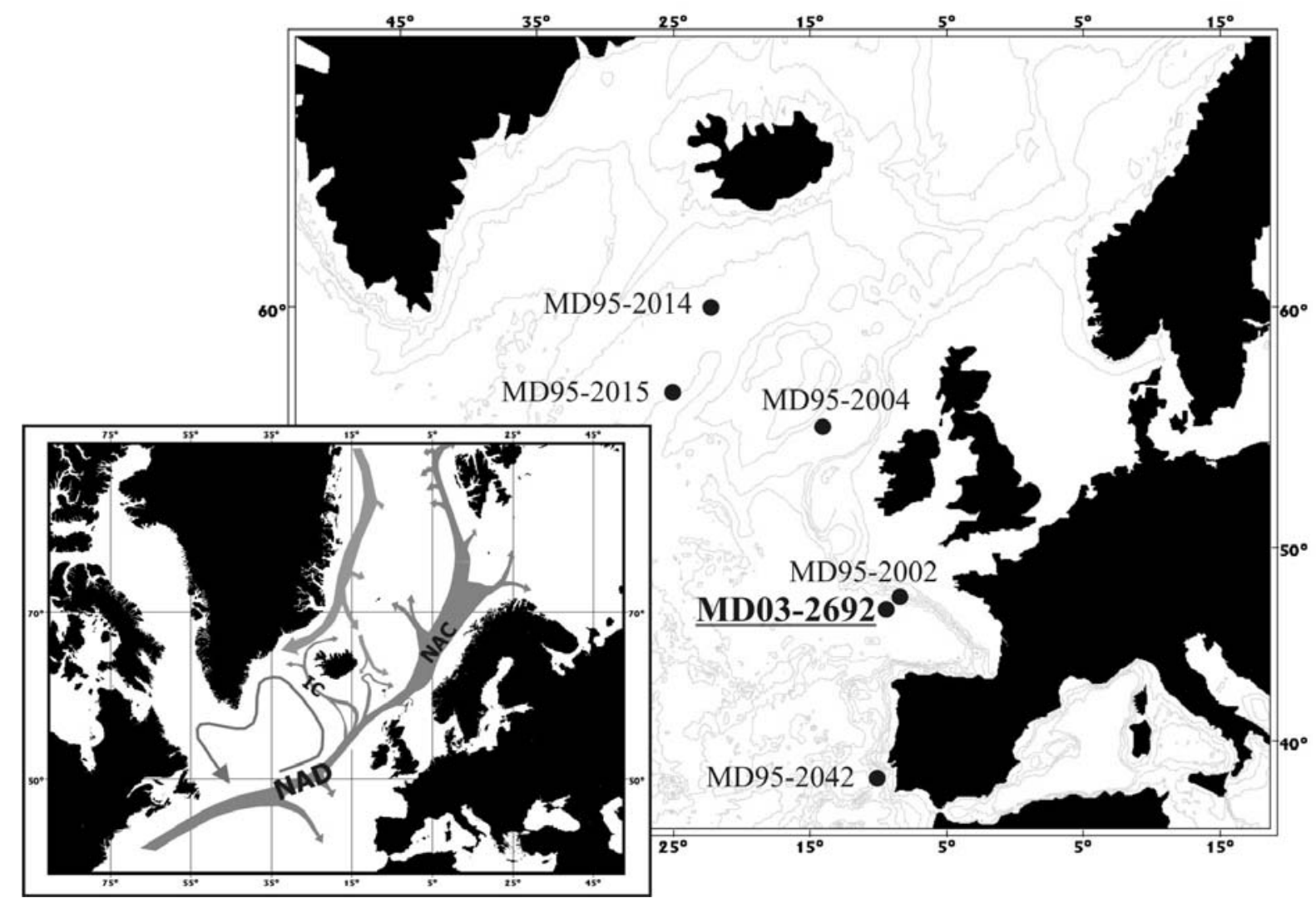

Figure 1: Location of the studied core MD03-2692 $\left(46^{\circ} 50^{\prime} \mathrm{N}, 9^{\circ} 31^{\prime} \mathrm{W}, 4064 \mathrm{~m}\right.$ water depth) and the other cores discussed in the paper: MD95-2002 (47 $27^{\prime} \mathrm{N}, 08^{\circ} 32^{\prime} \mathrm{W}, 2174 \mathrm{~m}$ depth), MD95-2004

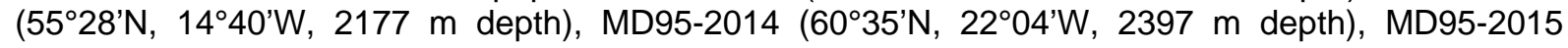
(58 $46^{\prime} \mathrm{N}, 2^{\circ} 57^{\prime} \mathrm{W}, 2630 \mathrm{~m}$ depth), and MD95-2042 (374' $\mathrm{N}, 10^{\circ} 10^{\prime} \mathrm{W}, 3146 \mathrm{~m}$ water depth). Northeastern Atlantic physiography: the first depth contour represents the $200 \mathrm{~m}$ isobar on the shelf. The next depth contour is the $1000 \mathrm{~m}$ isobar. At water depths greater than $1000 \mathrm{~m}$, the distance between the isobars is $1000 \mathrm{~m}$. The map in the bottom left-hand corner depicts the North Atlantic circulation pattern through the three main surface currents: North Atlantic Drift (NAD), North Atlantic Current (NAC), and Irminger Current (IC). 


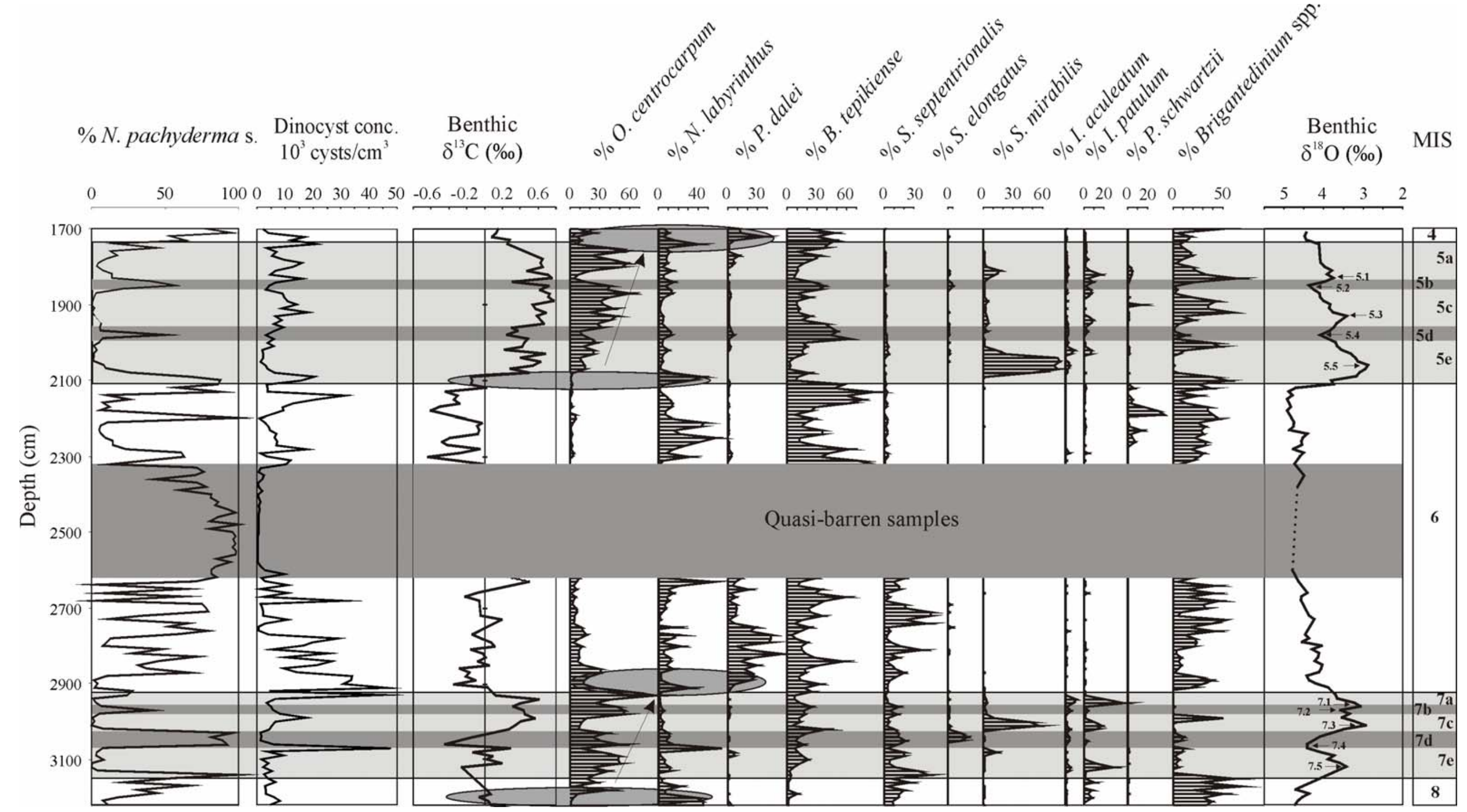


Figure 2: MD03-2692. Micropaleontological and geochemical data obtained for MIS 5 and MIS 7 and for parts of MIS 6. Core depths are displayed in centimetres along the vertical axis. The relative abundance of the dominant dinoflagellate cyst species and the dinocyst concentration are compared with the benthic isotopes $\left(\delta^{18} \mathrm{O}\right.$ and $\left.\delta^{13} \mathrm{C}\right)$, providing the stratigraphical framework for the core. The $N$. pachyderma sinistral percentage occurrence curve allows recognition of cold events within the Interglacial Complexes (dark grey bands within MIS 5 and MIS 7). The Marine Isotope Stages (MIS) are indicated at the right of the diagram. The isotopic events are marked by black arrows within the Interglacial Complexes (on the benthic $\delta^{18} \mathrm{O}$ curve). The dark grey band from 2370 to $2590 \mathrm{~cm}$ illustrates a distinctive event during MIS 6 with very high sedimentation rates (cf. Mojtahid et al., 2005) and extremely low total dinocyst concentration. Black arrows represented on the diagram of $O$. centrocarpum show the relative abundance of the species progressively increasing from the base to the top of each Interglacial Complex. Grey circles show the recurrent successions of species both at the onset and at the Termination of MIS 5 and MIS 7. 


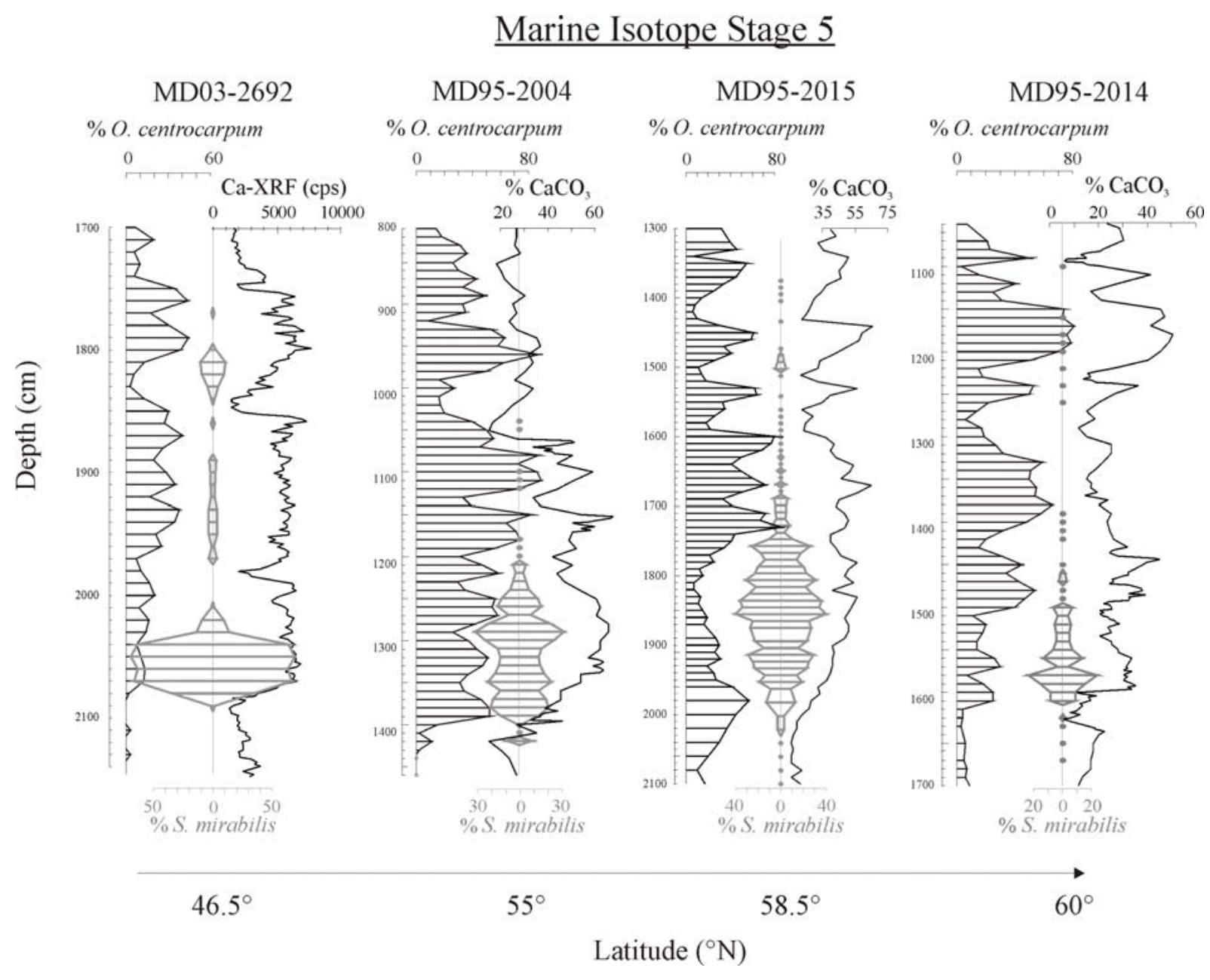

Figure 3: Comparison of the relative abundances of two dinocysts (Operculodinium centrocarpum and Spiniferites mirabilis) with Ca-XRF (counts/second) and $\mathrm{CaCO}_{3}(\%)$ data, in four cores from the northeastern Atlantic (Fig. 1 shows the precise location of each core). Spiniferites mirabilis appears during the Eemian in each core. Note the good correlation between the $\mathrm{CaCO}_{3}$ curve and Operculodinium centrocarpum percentages. 


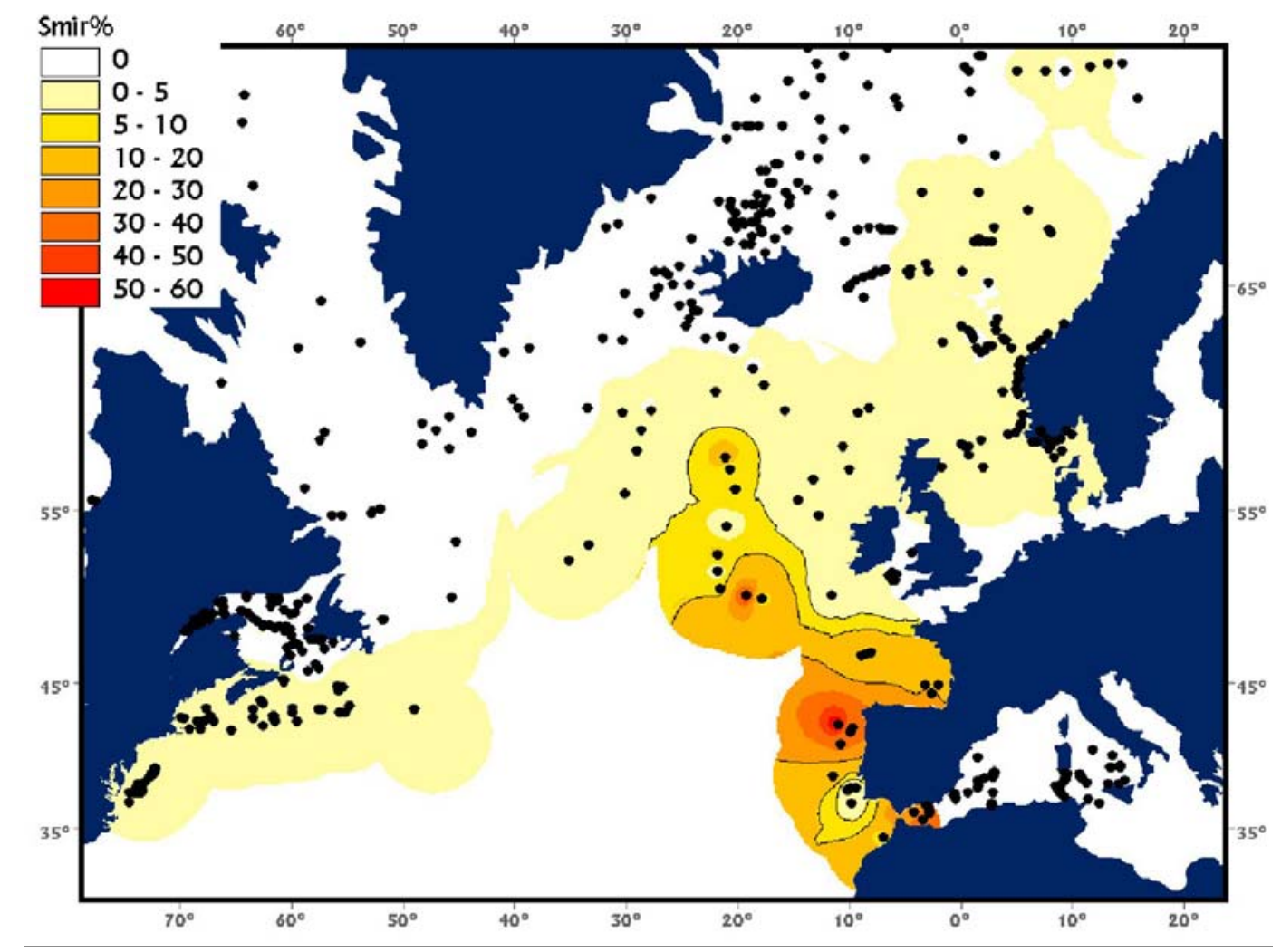

Figure 4: The distribution of Spiniferites mirabilis cysts in the North Atlantic Ocean at present. The modern 'Dinocyst $n=940$ ' data base (de Vernal et al., 2005) was used to map the distribution of Spiniferites mirabilis using Arcview GIS. The maximum occurrence of this species in the North Atlantic is located in the Bay of Biscay and off the coast of Portugal.

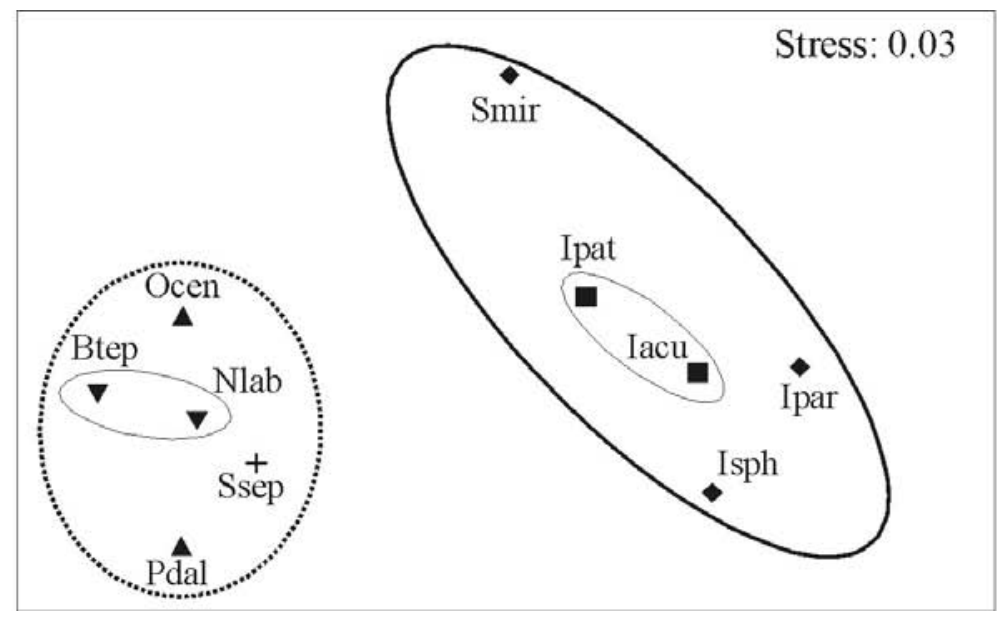

- Subpolar species

- Subpolar-temperate species

- Temperate species

- Subtropical species

Spiniferites
$+\quad$ septentrionalis

Figure 5: Ordination of the dominant species identified throughout the record by Multi-Dimensional Scaling 2D using the PRIMER application program on samples covering MIS 5 to MIS 7, thus including MIS 6 results. Symbols close to dinocyst name abbreviations allow identification of the present day species biozonations. Species abbreviations are: Bitectatodinium tepikiense, Btep; cysts of Pentapharsodinium dalei, Pdal; Operculodinium centrocarpum, Ocen; Nematophaeropsis labyrinthus, Nlab; Spiniferites septentrionalis, Ssep; Spiniferites mirabilis, Smir; Impagidinium patulum, Ipat; Impagidinium aculeatum, lacu; Impagidinium sphaericum, Isph; and Impagidinium paradoxum, Ipar. It shows which group of cyst Spiniferites septentrionalis is closest to. 

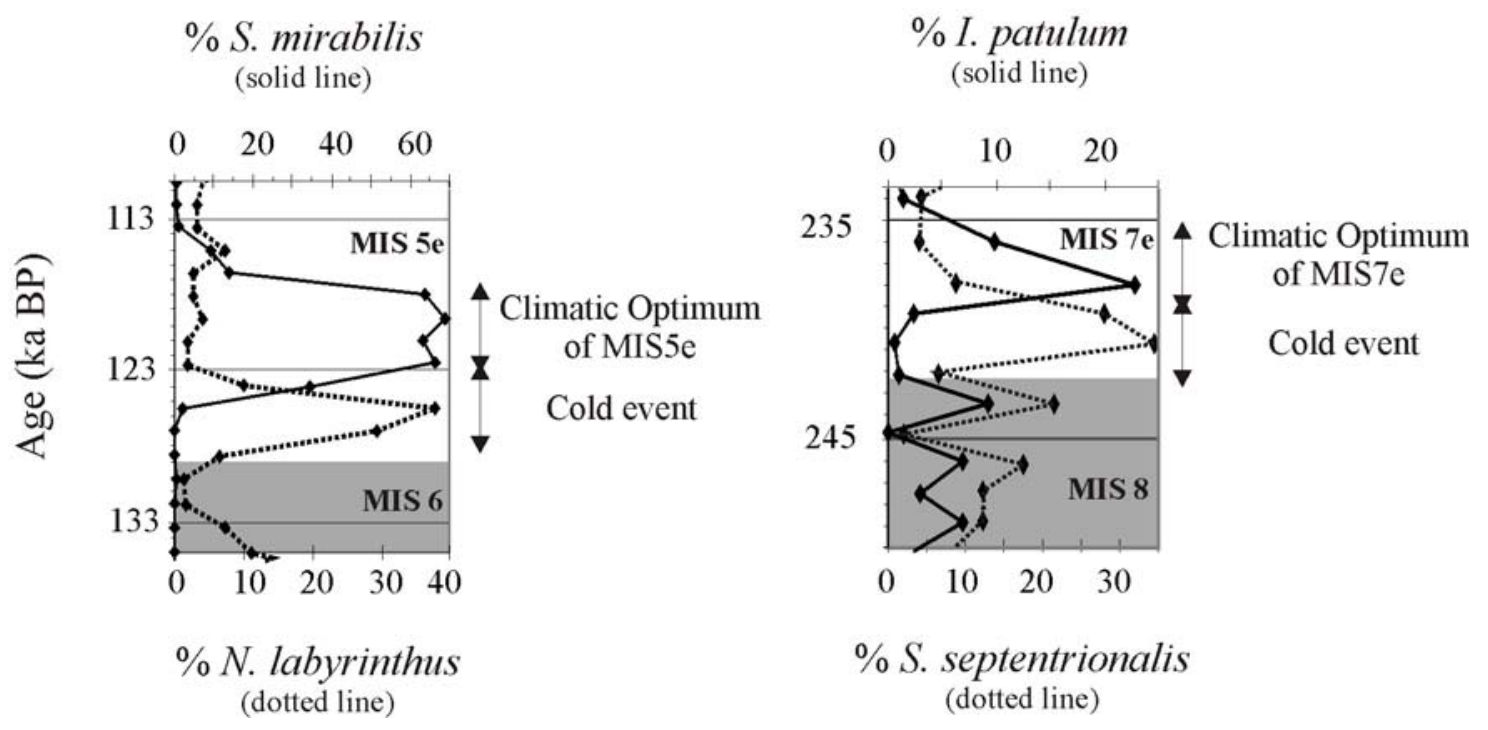

Figure 6: Relative abundance of selected dinocyst taxa marking the onset of MIS 5 and MIS 7 . Interglacial Complex boundaries are deduced from the benthic oxygen isotopes (mid-point). Nematosphaeropsis labyrinthus and Spiniferites septentrionalis mark cold periods at our latitude and are associated with respectively, the first part of MIS 5e, and MIS 7e. Climatic optima of these warm substages are then identified by Spiniferites mirabilis and Impagidinium patulum. 


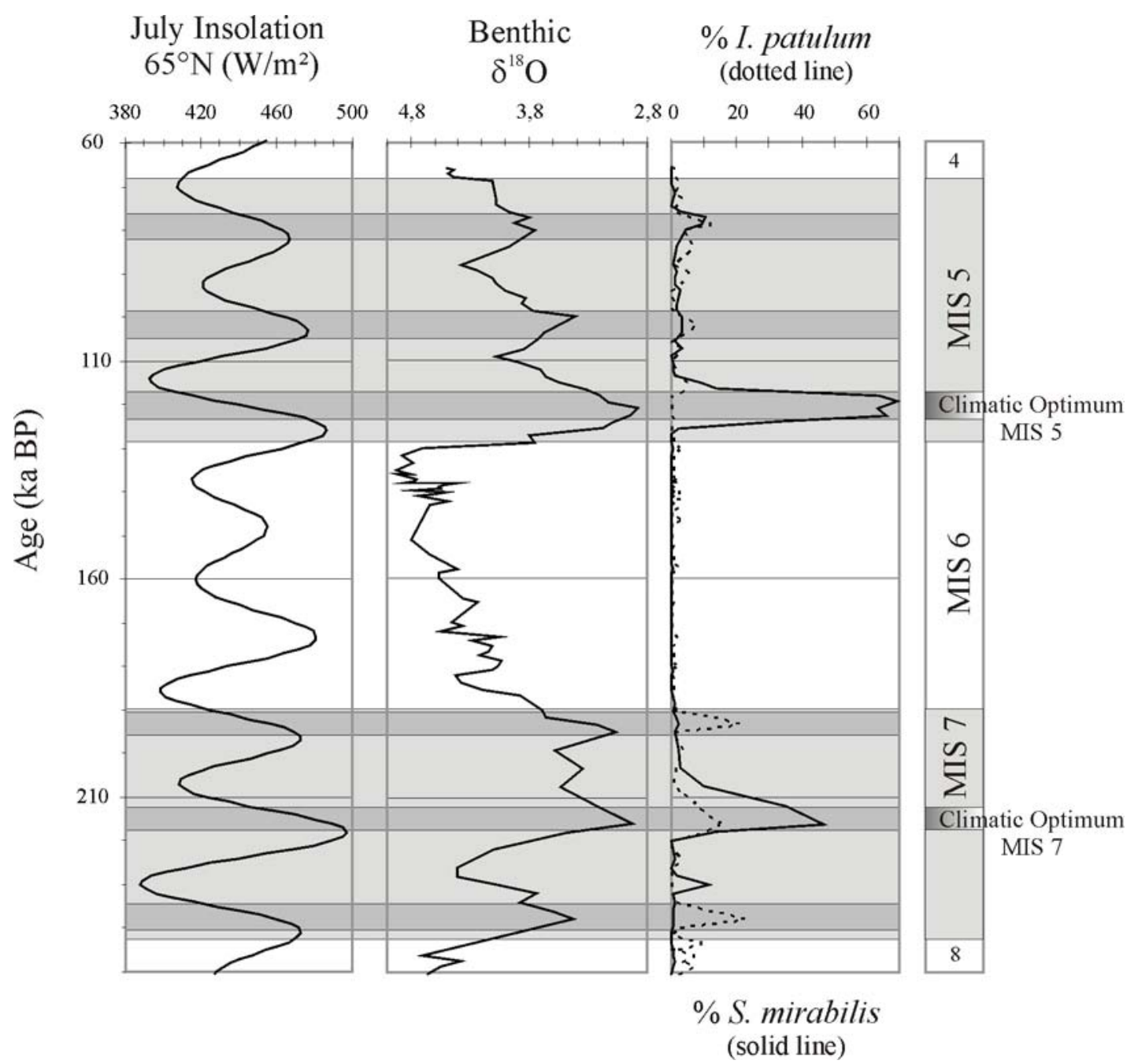

Figure 7: Diagram summarizing all the warm substages of MIS 5 and MIS 7 with the two warm major dinocyst species in the Bay of Biscay: Impagidinium patulum and Spiniferites mirabilis. The most important peaks of these taxa are consistently associated with the lightest benthic oxygen isotopes and with summer insolation maxima at $65^{\circ} \mathrm{N}$. Climatic optima of MIS 5 and MIS 7, respectively MIS 5e and MIS 7c, can be discriminated with higher percentages of Spiniferites mirabilis in each Interglacial Complex. Note the extremely high abundances of Spiniferites mirabilis during MIS 5. This corresponds to the MIS $5 \mathrm{e}$ plateau and represents the highest percentages of this species ever recorded in North Atlantic sediments. 


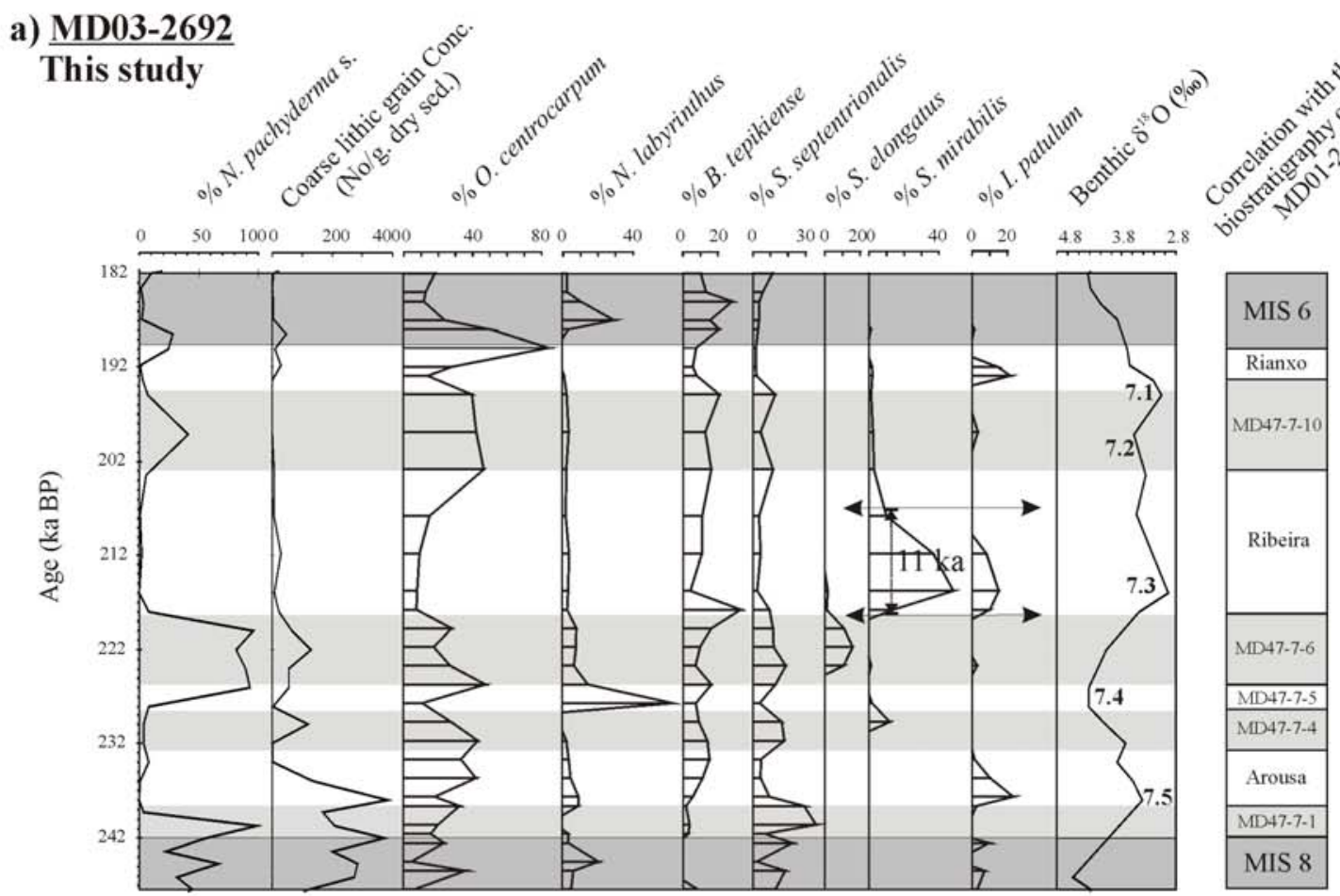

b) MD01-2447

From Desprat et al., 2006 (modified)

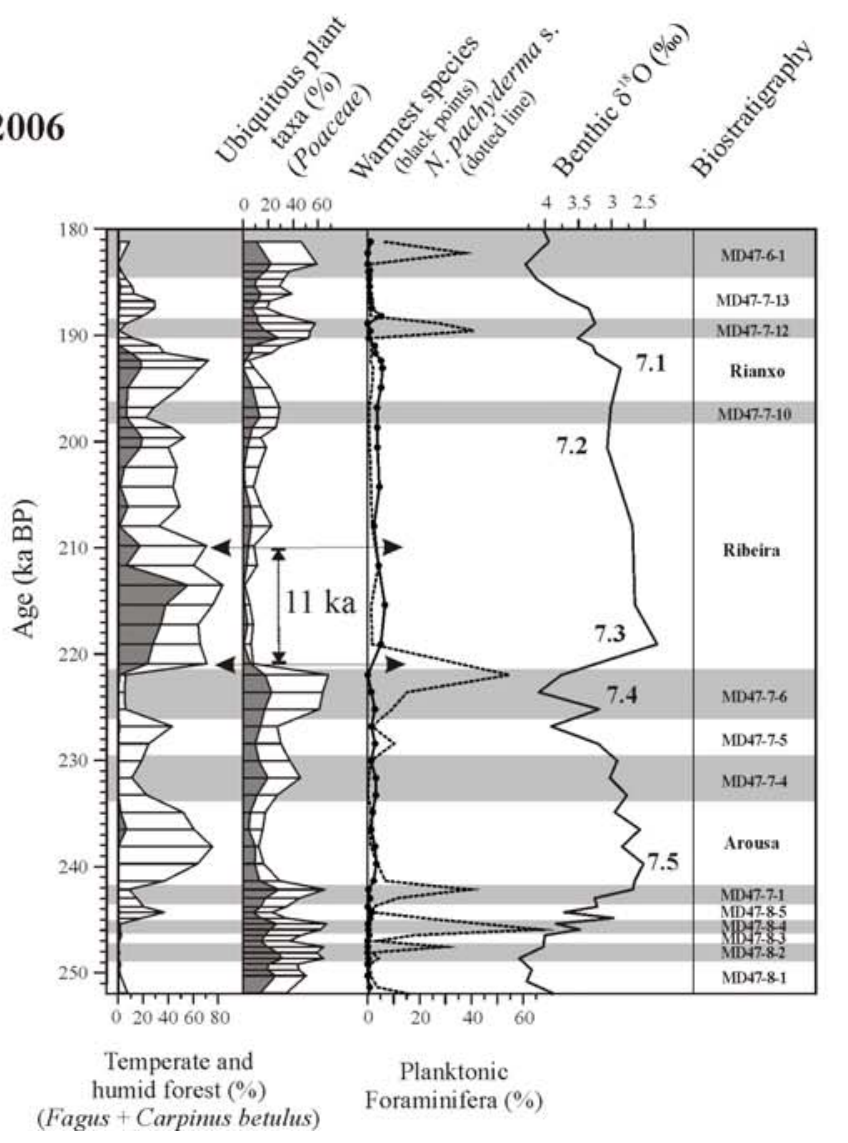

Figure 8: (a) MD03-2692 multiproxy record of MIS 7 including micropaleontological data (the relative abundances of $N$. pachyderma sinistral and dinocyst species), coarse detrital grain concentrations, and benthic $\delta^{18} \mathrm{O}$ data providing the stratigraphical framework. The climatic events have been correlated with the biostratigraphy of core MD01-2447 (Desprat et al., 2006). The micropaleontological (pollen and foraminifera relative abundances) and geochemimal (benthic $\delta^{18} \mathrm{O}$ curve) data in the latter 
core are presented in (b). With regard to foraminifer data, $N$. pachyderma sinistral relative abundances are shown by the dotted line. The curve with the black points illustrates the percentages of the warmest planktonic species. As for pollen data, temperate and humid forest taxa (comprising Fagus plus Carpinus betulus in grey), and ubiquitous plant taxa (without Ericaceae but with Poaceae in grey) are represented. On both diagrams ( $a$ and b), grey bands indicate cold events, and Rianxo, Ribeira and Arousa correspond to the three major forested phases during MIS 7. 


\section{a) Core MD03-2692}

Celtic Margin

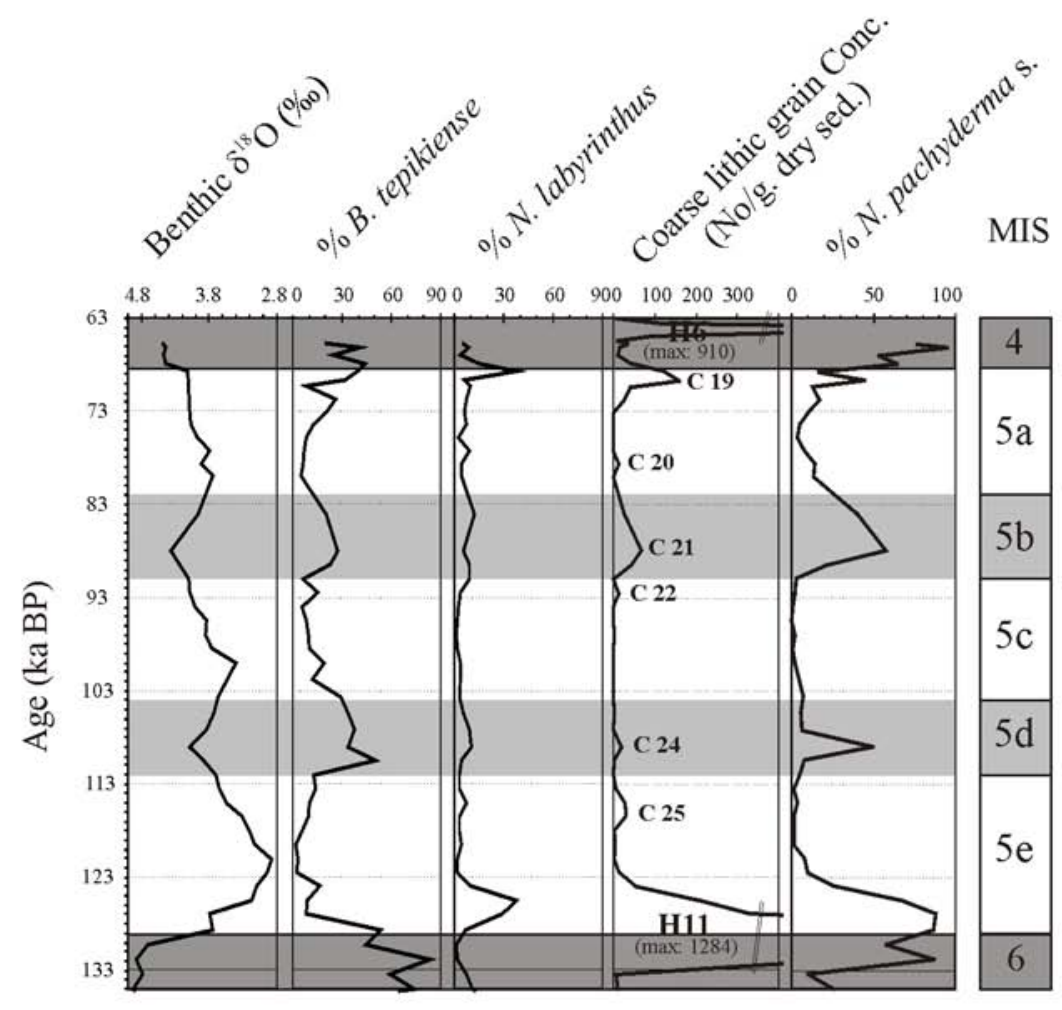

b) Core MD95-2004

Rockall Through c) Core MD95-2042

South Iberian Margin
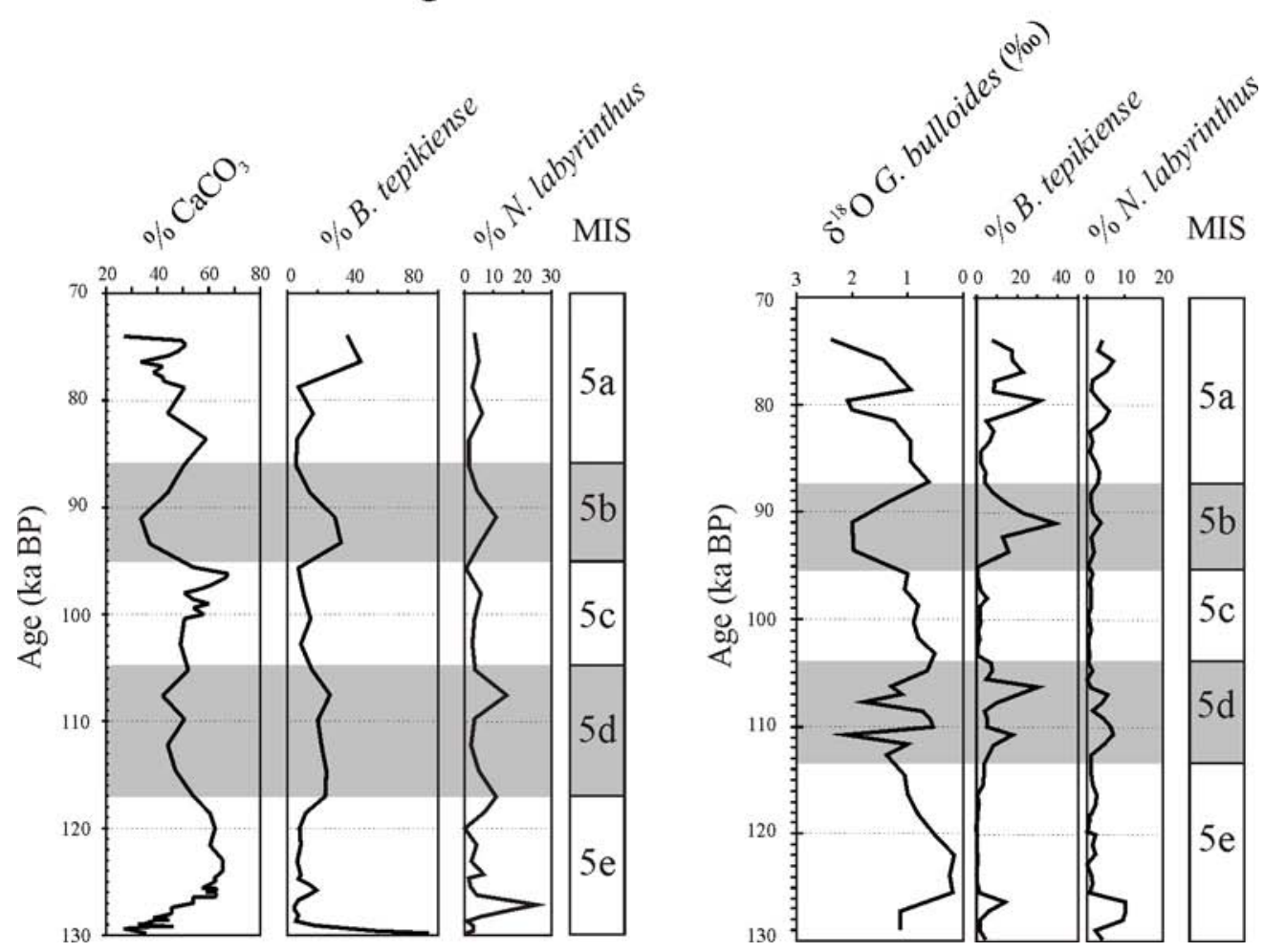

Figure 9: (a) Comparison of the relative abundances of Bitectatodinium tepikiense and Nematophaeropsis labyrinthus throughout MIS 5 with other proxies revealing cold events: benthic 
$\delta^{18} \mathrm{O}$, coarse $(>150 \mu \mathrm{m})$ detrital grain concentrations and $N$. pachyderma sinistral percentages. Heinrich events $\mathrm{H} 6$ and $\mathrm{H} 11$ as well as cold events $\mathrm{C} 19$ to $\mathrm{C} 25$ are positioned in accordance with McManus et al. (1994). Figures (b) and (c) reveal the occurrence of Bitectatodinium tepikiense and Nematophaeropsis labyrinthus in cores MD95-2004 and MD95-2042. Note the anticorrelation between the high percentages of Bitectatodinium tepikiense and the heavy benthic oxygen isotopes in the core MD95-2042. In the core MD95-2004, the stratigraphical framework is based on the CaCO3 curve as no benthic $\delta^{18} \mathrm{O}$ data were obtained. 